\title{
MODIFIED UNIVERSALISMS \& THE ROLE OF LOCAL LEGAL CULTURE IN THE MAKING OF CROSS-BORDER INSOLVENCY LAW
}

\begin{abstract}
ADRIAN WALTERS*
Cross-border insolvency law scholars have devoted much attention to theoretical questions of international system design. There is a general consensus in the literature that the ideal system would be a universalist system in which cross-border insolvencies would be administered in a single forum under a single governing law But scholars have paid less systematic attention to how a universalist system can be implemented in the real world by institutional actors such as legislatures and judges. This article seeks to redress the balance by discussing the reception of the UNCITRAL Model Law on Cross-Border Insolvency in the United States and the United Kingdom and exploring the role that judges play in harmonizing cross-border insolvency law.
\end{abstract}

As the Model Law is choice-of-law neutral, domestic enactments typically contain no express choice-of-law rules. Universalists urge judges to take their cue from modified universalism and interpret Model Law enactments in a manner that approximates to universalism's ideal "one court, one law" approach. But comparative analysis of AngloAmerican judicial practice reveals that the contours of modified universalism are contested. "Modified universalism" as it is understood in the United States implies that judges should presumptively defer to the law of the foreign insolvency proceeding (lex concursus). American universalists tend therefore to favor a strong, centralizing version of modified universalism. By contrast, British modified universalism has a forum law (lex fori) choice-of-law orientation. British modified universalism supports effective coordination of insolvency proceedings with one court having a primary coordinating role. But it lacks any commitment to a centralizing lex concursus rule in the absence of statutory mandate.

Framed by reference to this account of the Model Law's Anglo-American reception, the article argues that modified universalism offers no convincing theory of how a universalist system is to be institutionalized in practice in the absence of more and harder law, the province of legislatures. Competing versions of modified universalism cannot support an interpretive methodology capable of yielding global judge-made rules of private international law that would address the Model Law's choice-of-law indeterminacy.

\section{INTRODUCTION}

Cross-border insolvencies generate obvious coordination and governance difficulties. The basic problem - the presence of assets, claims, and creditors in more than one jurisdiction - is magnified by the prevalence of complex, multinational enterprises operating through multinational corporate group structures constituted 
according to the laws of numerous jurisdictions, onshore and offshore. Private international law unification instruments ${ }^{1}$ and other soft harmonization initiatives designed to nurture convergence among national insolvency laws ${ }^{2}$ and cooperation in cross-border insolvency cases have emerged to address these difficulties. ${ }^{3}$ A leading private international law instrument - the UNCITRAL Model Law on Cross-Border Insolvency ("the Model Law") ${ }^{4}$ - marked its twentieth anniversary in 2017. Supporters hail the Model Law as an embodiment of "modified universalism" that provides a foretaste of a fully universalist system for fair and efficient administration of cross-border insolvencies in a single forum under a single law. ${ }^{5}$ On the theoretical plane, universalist

\footnotetext{
* Ralph L. Brill Professor of Law, Chicago-Kent College of Law, Illinois Institute of Technology (US) and Professor, Centre for Business and Insolvency Law, Nottingham Law School, Nottingham Trent University (UK). All uniform resource locators cited in footnotes were live on October 31, 2017. I thank participants in a panel on Judges and Judging at the Law and Society Association Annual Meeting held in Mexico City in June 2017 and an internal workshop held at Chicago-Kent in August 2017 for comments on early drafts. I particularly thank Cody Lipke (Chicago-Kent Class of 2018) for research assistance and the following for insightful comments and discussions: Tim Barnes, Drew Dawson, Amalie Frese, Graham Ferris, Dan Glosband, Allan Gropper, Steve Harris, Rick Mason, Irit Mevorach, Sarah Paterson, Mark Rosen, Ray Warner, Jay Westbrook, and Tally Wiener. The usual disclaimers apply. The article was supported by a generous summer grant from Chicago-Kent College of Law. I use the terms "bankruptcy" and "insolvency" interchangeably. In the US "bankruptcy" cases can affect both individuals and legal entities. In other countries, such as the UK, "bankruptcy" refers only to individuals and does not include entities, whereas "insolvency" is all embracing.

${ }^{1}$ Of which the two leading examples are Regulation (EU) No. 2015/848 of the European Parliament and of fthe Council of 20 May 2015 on insolvency proceedings (recast), 2015 O.J. (L. 141/19) [hereinafter EU INSOLVENCY REGULATION] (revising and recasting Council Regulation (EC) No. 1346/2000 of 29 May 2000 of 29 May 2000 on insolvency proceedings, 2000 O.J. (L. 60/1)) and the UNCITRAL Model Law on Cross-Border Insolvency, infra note 4.

${ }^{2}$ See U.N. COMM'N ON INT'L TRADE LAW, UNCITRAL LEGISLATIVE GUIDE ON INSOLVENCY LAW, PARTS 1 \& 2 (2004), PART 3 (2010), PART 4 (2013), http://www.uncitral.org/uncitral/en/uncitral texts/insolvency/2004Guide.html.

${ }^{3}$ See AMERICAN LAW INSTITUTE \& INTERNATIONAL INSOLVENCY INSTITUTE, TRANSNATIONAL INSOLVENCY: GLOBAL PRINCIPLES FOR COOPERATION IN INTERNATIONAL INSOLVENCY CASES (2012) [hereinafter GLOBAL PRINCIPLES].

${ }^{4}$ U.N. COMM'N ON INT'L TRADE LAW, MODEL LAW ON CROSS-BORDER INSOLVENCY (1997) WITH GUIDE TO ENACTMENT (revised 2013), U.N. Sales No. E.99.V.3 (1999) [hereinafter MODEL LAW \& GUIDE TO ENACTMENT].

${ }^{5}$ See Jay L. Westbrook, National Regulation of Multinational Default, in ECONOMIC LAW AND JUSTICE IN TIMES OF GLOBALISATION 777, 779 (Mario Monti et al eds., 2007) [hereinafter Westbrook, National Regulation] (the Model Law "tacitly adopted the approach of modified universalism"); infra Section I.B.
} 
scholars have claimed victory. ${ }^{6}$ But despite universalism's theoretically triumphant template for a market symmetric, welfare maximizing international insolvency system, universalists have no convincing account of how their system can be institutionalized in practice without a comprehensive insolvency convention or global courts and centralized enforcement mechanisms.

Universalism's ambitions are grand. Yet its methods are pragmatic and realistic. ${ }^{7}$ Universalists recognize that global conventions are hard to accomplish ${ }^{8}$ and that a world government will not be established any time soon. They accept that the vision of "one forum, one law" can only be realized in baby steps. Methodologically, they favor slow burning techniques - at the international level, legislative incrementalism designed to create conditions for more intensive interstate cooperation over time; ${ }^{9}$ at the domestic level, purpose oriented judicial interpretive practice embracing comity and fidelity to international system building. ${ }^{10}$ They deploy modified universalism both as a theory to

\footnotetext{
${ }^{6}$ See John Pottow, Beyond Carve-Outs and Toward Reliance: A Normative Framework for Cross-Border Insolvency Choice of Law, 9 BROOK. J. CORP. FIN. \& COM. L. 202, 202 (2014) [hereinafter Pottow, Beyond Carve Outs] ("And it has been settled. The universalists, at least as a normative matter, appear to have won.").

${ }^{7}$ See Jay L. Westbrook, Chapter 15 at Last, 79 AM. BANKR. L.J. 713, 716 (2005) [hereinafter Westbrook, Chapter 15 at Last] ("Universalism is now characterized as modified universalism, meaning a pragmatic approach that seeks to move steadily toward the ideal of universal proceedings while accepting the reality of step-by-step progress through cooperation.").

${ }^{8}$ See Westbrook, National Regulation, supra note 5, 778-79 ("The ideal of universalism is of a single primary bankruptcy proceeding in the debtor's home country, with courts elsewhere acting in an ancillary or supportive role to the primary court, resulting in unitary administration of assets under one bankruptcy law. Because that result would require sophisticated international agreements, the ideal remains some distance away").

${ }^{9}$ See John Pottow, Procedural Incrementalism: A Model for International Bankruptcy, 45 VA. J. INT'L. L. 935 (2005) [hereinafter Pottow, Procedural Incrementalism]. On the role of incrementalism in international lawmaking generally see also Susan Block-Lieb \& Terence C. Halliday, Incrementalisms in Global Lawmaking, 32 BROOK. J. INT'L. L. 851 (2007) [hereinafter Block-Lieb and Halliday, Incrementalisms]; Less is More in International Private Law, 3 NOTT. INSOLV. \& BUS. L. e-J. 43 (2015), https://www4.ntu.ac.uk/nls/document_uploads/174815.pdf [hereinafter Block-Lieb \& Halliday, Less is More]. Block-Lieb and Halliday focus on how international law is made and develops. They do not pursue an explicitly universalist agenda.

${ }^{10}$ See MODEL LAW, supra note 4, art.8; Jay L. Westbrook, Interpretation Internationale, 87 TEMP. L. REV. 739 (2015) [hereinafter Westbrook, Interpretation Internationale].
} 
undergird a transitional system sensitive to the interests of sovereign states and local stakeholders pending the establishment of a fully universalist system, and as a normatively laden method or principle that, applied correctly, will help bring about a fully universalist system. Modified universalism as method has an ideological and teleological quality - domestic courts should "cooperate to achieve a result as close to the ideal as circumstances and existing domestic law permit." 11 This approximation of the "real" to the "ideal", or the present state to the desirable end state, resembles how classical economists have historically justified government intervention in real markets using the concept of a perfect market, operating under conditions of perfect competition, as a guide to policy and practice. ${ }^{12}$

In their implicit commitment to global free markets, universalists naturally assume that the job of international commercial law is to create frictionless and transcendent international legal frameworks that facilitate efficient allocation of global capital by increasing predictability and reducing transaction costs ex ante (when credit is extended) and ex post (when debtors default). But as deglobalization takes hold in the post-2008 world, notably in the West, global markets and free trade are increasingly

\footnotetext{
${ }^{11}$ See Jay L. Westbrook, A Global Solution to Multinational Default, 98 MICH. L. REV. 2276, 2301 (2000) [hereinafter Westbrook, Global Solution]. See also Westbrook, National Regulation, supra note 5, 779.

${ }^{12}$ I confess here my own Burkean animus against the design and benchmarking of systems by reference to abstract desiderata and my preference instead for going forward from real world premises. See EDMUND BURKE, SPEECH ON REFORM OF REPRESENTATION IN THE HOUSE OF COMMONS (1784), http://www.econlib.org/library/LFBooks/Burke/brkSWv4c2.html ("It seems to me a preposterous way of reasoning, and a perfect confusion of ideas, to take the theories, which learned and speculative men have made from...government, and then, supposing it made on these theories, which were made from it, to accuse government as not corresponding with them. I do not vilify theory and speculation... No; whenever I speak against theory, I mean always a weak, erroneous, fallacious, unfounded or imperfect theory; and one of the ways of discovering that it is a false theory is by comparing it with practice."). See also Ronald H. Coase, The Regulated Industries: A Discussion, 54 AM. ECON. REV. (PAPERS \& PROC.) 194, 195 (1964) ("Contemplation of an optimal system may suggest ways of improving the system...[and] it may go far to providing a solution. But in general its influence has been pernicious. It has directed... attention away from the main question, which is how alternative arrangements will actually work in practice.”).
} 
under attack. ${ }^{13}$ And, thus, the prospects for universalism's constitutive agenda - the establishment of worldwide insolvency infrastructure in support of global trading and credit markets - now seem highly contingent. Indeed, in the current global economic and geopolitical context, the mismatch between the scale of universalism's theoretical ambitions and the gradualism of its practical working methods is striking.

A journey of a thousand miles begins with the first step ${ }^{14}$ and the progress made to date in international insolvency cooperation cannot be underestimated. Meaningful and effective coordination involving courts and practitioners has led to successful multijurisdictional resolutions in large, complex cross-border insolvency cases such as Maxwell, Lehman, and Nortel. International cooperation has proved possible notwithstanding feasibility constraints. But universalists have not convincingly demonstrated how progress will be made towards universalism other than in fits and starts. Go too fast and countries may push back. Go too incrementally and there is a risk of stasis - a system in a state of semi-permanent transition at best - akin to getting stuck part way up a hill. ${ }^{15}$

My starting assumption is that universalists are right that a universalist system would be the best (or least worst) system we could devise to address the social cost

\footnotetext{
${ }^{13}$ See, e.g. Globalisation: The Rise and Fall of an Idea that Swept the World, THE GUARDIAN, Jul. 14, 2017; Management Theory is Becoming a Compendium of Dead Ideas, THE ECONOMIST, Dec. 17, 2016; Risk of Deglobalization Hangs Over World Economy, WALL ST. J., Oct. 5, 2016. See also Frank J. Garcia, Introduction: Globalization, Power, States, and the Role of Law, 54 B.C.L. REV. 903, 904-5 (2013) (discussing how globalization has both weakened and strengthened states).

${ }^{14}$ Westbrook, Chapter 15 at Last, supra note 7, 716, fn.23. The proverb (or a variant thereof) is usually attributed to Lao-Tzu, the Chinese philosopher said to have been the founder of Taoism.

${ }^{15}$ A self-described "aggressive universalist" whose work unpacks modified universalism's incremental methodology, acknowledges this risk. See Pottow, Beyond Carve-Outs, supra note 6, 209 ("The glass half full narrative is that modest reforms will tear down sovereign mistrust and participant-actors' skepticism of the evils of applying foreign insolvency law. The half empty narrative, however, is that these modest reforms will get readily enacted with self-congratulatory back-slapping but then stall without further progress when the truly difficult sovereignty concessions have to be made (e.g. selection of priority and distribution rules.)").
} 
problems that arise from cross-border insolvencies. My differences with leading universalists are methodological. In the present state of affairs, modified universalism can only beget universalism through the agency of various state and non-state actors: legislatures (international and domestic), courts, practitioners, and professional bodies (through the influence they exert as non-state actors in legislative processes and as providers of continuing professional development and know-how to their members). The roles these actors play, the incentives they have, and the constraints they face, in actualizing universalism in practice in the real world, demand attention. To date, there has been little systematic discussion of institutional actors in the legal literature on international insolvency. ${ }^{16}$ The "universalism versus territorialism" debate in the academic literature operates at a high, theoretical level of generality and focuses on "blue skies" questions about what is the normatively appropriate model or system for governing cross-border insolvencies. ${ }^{17}$ The practitioner literature, often excellent at capturing case law developments and practice innovations, ${ }^{18}$ serves the "street" or micro-level needs of its primary audience. What we lack is an abundance of meso-level scholarship analyzing how the international insolvency system functions, having regard to the main actors

\footnotetext{
${ }^{16}$ A notable exception is the work of Terry Halliday and Susan Block-Lieb on international legislatures and standard-setting. See, e.g. Block-Lieb \& Halliday, Incrementalisms, supra note 9; Terrence C. Halliday, Josh Pacewicz \& Susan Block-Lieb, Who Governs? Delegations in Global Trade Lawmaking, 7 REG. \& GOVERNANCE 279 (2013); Susan Block-Lieb \& Terrence C. Halliday, GLOBAL LAWMAKERS: INTERNATIONAL ORGANIZATIONS AND THE CRAFTING OF WORLD MARKETS (2017).

${ }^{17}$ This article assumes some familiarity with the contours of this debate. The various positions are staked out in the following law review articles: Jay L. Westbrook, Theory and Pragmatism in Global Insolvencies: Choice of Law and Choice of Forum, 65 AM. BANKR. L.J. 457 (1991); [hereinafter Westbrook, Theory and Pragmatism]; Lynn M. LoPucki, Cooperation in International Bankruptcy: A Post-Universalist Approach, 84 CORNELL L. REV. 696 (1999) [hereinafter LoPucki, Cooperation in International Bankruptcy]; Lynn M. LoPucki, The Case for Cooperative Territoriality in International Bankruptcy, 98 MICH. L. REV. 2216 (2000) [hereinafter LoPucki, Cooperative Territoriality]; Westbrook, Global Solution, supra note 11; Edward J. Janger, Universal Proceduralism, 32 BROOK. J. INT'L. L. 819 (2007).

${ }^{18}$ See, e.g., Peter M. Gilhuly et al, Bankruptcy Without Borders: A Comprehensive Guide to the First Decade of Chapter 15, 24 AM. BANKR. INST. L.R. 47 (2016); R. Craig Martin \& Cullen Drescher Speckhart, CHAPTER 15 FOR FOREIGN DEBTORS (2015).
} 
within the system, and their interactions, processes, instrumentalities, methods, and frames of reference. We cannot hope to understand fully the dynamics of the system and the possible trajectories of its evolution without more comparative accounts of how the work of coordinating cross-border insolvency cases actually gets done iteratively on the ground over time.

To mark the twentieth anniversary of the Model Law, this article reviews experiences in two leading common law countries that were early adopters of the Model Law - the United States and the United Kingdom ${ }^{19}$ - to explore the Model Law's selffulfilling limits as a coordinating instrument and the limits of modified universalism as a method for propelling the universalist agenda forward. I focus in particular on the frontline role domestic courts play in cross-border insolvency governance, in implementing international insolvency law, and in linking the international and domestic legal orders. While the Model Law has successfully promoted domestic recognition of foreign insolvency proceedings, results have been predictably less consistent where it acts as a guiding framework and leaves local legislatures wide discretion on the detail of implementation. This is especially so when foreign insolvency trustees - "foreign representatives" in Model Law parlance - request domestic judges to grant discretionary relief entailing the application of, or deference to, foreign insolvency law. Local Model Law enactments confront judges with a species of interlegality ${ }^{20}$ taking the form of an interaction between the international and domestic legal orders. However, beyond

\footnotetext{
${ }^{19}$ The selection is partly pragmatic. These are the countries with which I am most familiar and my personal standpoint is that of a transatlanticist striving to see the UK through US eyes and vice versa. Pragmatism aside, the US handles significantly more cases than any other enacting state and is by some distance the leading producer of Model Law jurisprudence, while the UK's approach is representative of developments in the British common law world.

${ }^{20}$ WILLIAM TWINING, GLOBALISATION \& LEGAL THEORY, 229-31 (2000) (discussing BOAVENTURA DE SOUSA SANTOS, TOWARDS A NEW LEGAL COMMON SENSE: LAW, GLOBALIZATION, AND EMANCIPATION (2002)).
} 
aspirational statements of legislative purpose, Model Law enactments provide these "glocal" 21 judges with limited guidance in circumstances where foreign representatives request discretionary relief. With judges sometimes forced to choose between purposeoriented international norms and domestic law, it is hardly surprising that "glocal" judging generates inconsistent outcomes that do not satisfy universalists. ${ }^{22}$ Ultimately, judicial authority is constituted by domestic legal frameworks and cultures, which exert a gravitational force when judges encounter hard questions. Judges, as creatures of their own systems, work within leeways that are shaped by the manner of local legislative implementation and the judicial sense of how the Model Law "fits" within domestic cross-border insolvency law as a whole.

Requests for relief often implicate choice-of-law questions. But the Model Law is choice-of-law neutral and domestic enactments typically contain no express choice-oflaw rules. Universalists urge judges to take their cue from modified universalism and interpret Model Law enactments in a system-oriented way with regard to universalist goals. But modified universalism is not yet a unified theory with an agreed set of characteristics. Modified universalism as it is generally understood by US scholars implies that judges should defer to the law of the foreign insolvency proceeding (the lex concursus) wherever possible, so as to mimic universalism's preferred "one court, one law" approach. This is a strong "centralizing" version of modified universalism, associated with leading scholars, notably Jay Westbrook, that favors the closest possible

\footnotetext{
${ }^{21}$ A term the origins of which are murky but which distils the idea of "thinking globally, acting locally", e.g. through the adaptation of global brands to local markets.

${ }^{22}$ Some commentators attribute the inconsistency to modified universalism's inbuilt concession to local interests and regard it as no bad thing. See, e.g, Edward S. Adams \& Jason K. Fincke, Coordinating CrossBorder Bankruptcy: How Territorialism Saves Universalism, 15 COLUM. J. EUR. L. 43 (2009) [hereinafter Adams \& Fincke, Coordinating Cross-Border Bankruptcy].
} 
approximation of judicial practice to the universalist ideal. But modified universalism, as practiced in the UK under the Model Law and at common law, is a weaker strain that sticks resolutely to a forum insolvency law (lex fori) choice-of-law orientation. British modified universalism supports effective coordination of insolvency proceedings with one court having a primary coordinating role. But it lacks any commitment to a fully centralizing lex concursus rule in the absence of a specific domestic statutory mandate. In this "coordinating" version of modified universalism, local courts will try, where they deem it permissible, to provide foreign representatives with direct assistance under local insolvency law without the foreign representative needing to commence a duplicative, parallel insolvency proceeding.

The article proceeds in four sections. Section I reviews the Model Law and provides general background on its adoption and operation to date. It includes a brief account of the Model Law's connection to the universalist agenda and a synthesis of available empirical evidence suggestive of its successes and limits.

Section II frames the role of "glocal" judges as transnational, frontline actors in the international insolvency system seeking to make sense of local enactments of nonbinding international law within the context of local legal systems and cultures. In so doing, it pushes back against the tendency in academic discourse to characterize international insolvency cooperation within interstate framings premised on utilitarian notions of aggregate welfare (as per the "universalism" versus "territorialism" debate) while paying no attention to the mechanics of actual decision-making which relies on judicial agency. 
Section III compares the reception of the Model Law in the US and the UK and the implications of Anglo-US reception for our understanding of modified universalism as a vehicle for harmonization. In the US, a powerful commitment to comity reinforces Model Law goals and instantiates a relatively strong centralizing version of modified universalism. However, some US courts decline deference to foreign court orders or foreign insolvency law either by prioritizing fidelity to domestic statutory text (meaning the Bankruptcy Code into which the Model Law has been incorporated) over an internationally oriented purposive interpretive method or by using Model Law concepts such as "sufficient protection" as a basis for resistance.

In the UK, the Supreme Court's 2012 decision in Rubin v. Eurofinance $S A^{23}$ subordinates the UK's Model Law enactment to other pre-existing private international law frameworks and carves out from its scope the recognition and enforcement of foreign insolvency-related judgments, such as asset recovery orders or discharges. Rubin and subsequent cases, including cases from the British offshore world decided by the Judicial Committee of the Privy Council, adumbrate a weaker version of modified universalism that signals a powerful commitment to two related ideas: first, in keeping with the British common law concept of ancillary winding up, that jurisdiction to assist in cross-border cases is intrinsically domestic; and, second, that courts should not cooperate in a given instance without a specific, enumerated domestic statutory or common law basis for the requested assistance.

As modified universalism's choice-of-law orientation is contested and its strong and weak variants are self-reinforcing products of pre-existing legal cultural divergence, it cannot serve as a uniform guiding principle for resolving the inevitable tension between ${ }^{23}$ [2012] UKSC 46, [2013] 1 A.C. 236 (UK). 
the universal aspirations of international law and its local application. ${ }^{24}$ To ask it to play such a role as regards choice-of-law is to ask courts to resolve questions about what an appropriate choice-of-law framework should look like that are best suited to further legislative determination. Accordingly, I argue towards the end of Section III that Professor Westbrook's notion of a goals-oriented international interpretive rule ${ }^{25}$ is at odds with the realities of the Model Law's divergent Anglo-US implementation and reception.

Section IV offers some brief concluding thoughts about the respective roles of legislatures and judges in the evolution of cross-border insolvency law and in the further consolidation of the international forum shopping system.

\section{THE UNCITRAL MODEL LAW: THE FIRST TWENTY YEARS IN OVERVIEW}

A. Origins, Objectives, and Scope

The Model Law is a procedural private international law instrument that was adopted by UNCITRAL on May 31, $1997 .{ }^{26}$ The Model Law's aims are set out concisely in its preamble:

The purpose of this Law is to provide effective mechanisms for dealing with cases of cross-border Insolvency so as to promote the objectives of:

\footnotetext{
${ }^{24}$ See Helmut Philipp Aust, Between Universal Aspiration and Local Aspiration and Local Application: Concluding Observations, in THE INTERPRETATION OF INTERNATIONAL LAW BY DOMESTIC COURTS (Helmut Phillip Aust \& Georg Nolte eds., 2015).

${ }^{25}$ See Westbrook, Interpretation Internationale, supra note 10.

${ }^{26}$ Report of the United Nations Commission on International Trade Law on the Work of its Thirtieth Session, (1997), U.N. Doc. A/52/17 (1997). For background see generally André J. Berends, The UNCITRAL Model Law on Cross-Border Insolvency: A Comprehensive Overview, 6 TUL. J. OF INT'L. \& COMP. L. 309 [hereinafter Berends, UNCITRAL Model Law]; Jenny Clift, The UNCITRAL Model Law on Cross-Border Insolvency - A Legislative Framework to Facilitate Coordination and Cooperation in CrossBorder Insolvency, 12 TUL. J. OF INT'L. \& COMP. L. 307 (2004) [hereinafter Clift, UNCITRAL Model Law]; Jenny Clift, Choice of Law and the UNCITRAL Harmonization Process, 9 BROOK. J. CORP. FIN. \& COM. L. 20 (2014) [hereinafter Clift, Choice of Law].
} 
(a) Cooperation between the courts and other competent authorities of this State and foreign States involved in cases of cross-border insolvency;

(b) Greater legal certainty for trade and investment;

(c) Fair and efficient administration of cross-border insolvencies that protects the interests of all creditors and other interested persons, including the debtor;

(d) Protection and maximization of the value of the debtor's assets: and

(e) Facilitation of the rescue of financially troubled businesses, thereby protecting investment and preserving employment.

Its origins can be traced back to a joint colloquium organized by UNCITRAL and INSOL International, a prominent umbrella organization of national associations of insolvency professionals, held in Vienna in 1994. Building on earlier texts developed by organizations, such as the International Bar Association, an UNCITRAL Working Group, consisting of delegates from UNCITRAL member states and observers from professional organizations including INSOL and the International Bar Association, drafted and agreed the text of the Model Law and the accompanying Guide to Enactment over the course of four meetings between November 1995 and January 1997 - a remarkable achievement in such a short time frame. Since 1997 the text of the Model Law has not been amended but a revised Guide to Enactment was issued in January 2014.

The speed with which the Model Law was agreed can be attributed to several factors. First, the Working Group's deliberations were informed by developments in Europe where, after a stop-start process over a thirty-year period, the EU's member states had finally agreed on the text of a Bankruptcy Convention. ${ }^{27}$ Second, the Working Group drew on recent initiatives by professional organizations, chiefly the International Bar Association. Third, many of the Working Group's members had been involved in these roughly contemporaneous endeavors. Fourth, the Working Group chose to draft a model

\footnotetext{
${ }^{27}$ See Berends, UNCITRAL Model Law, supra note 26, 316-17. The Bankruptcy Convention never came into effect. However, it was resurrected in 2000 as an EU regulation. For background, see generally, IAN F. FLETCHER, INSOLVENCY IN PRIVATE INTERNATIONAL LAW 339-58 (2005) [hereinafter FLETCHER, INSOLVENCY IN PRIVATE INTERNATIONAL LAW].
} 
law rather than a convention on the assumption that the provisions of a non-binding model law would be easier to draft and agree than a "take-it-or-leave-it" convention.

The choice of a model law over a convention demonstrates that the approach of the Model Law's framers was pragmatic and incremental. The legislative consensus was that the Model Law should be narrow in scope and primarily procedural in orientation thus allowing progress to be made while reducing the risk that countries would not buy in. Insightful commentator and self-described universalist, John Pottow, characterizes the underlying strategy as:

procedural incrementalism, a form of incrementalism that moves for gradually increasing subjugation of sovereignty on seemingly less threatening procedural matters as a form of acclimation to the imposition of foreign law (or at least foreign court control over) domestic insolvency proceedings. ${ }^{28}$

Thus, while a global convention was favored as the optimal solution, ${ }^{29}$ the idea of a convention was kicked into the long grass, where it has largely remained. ${ }^{30}$

Comprehensive private international law instruments govern questions of venue, choice-of-law, the mutual recognition and enforcement of foreign proceedings and orders, and parallel proceedings (lis alibi pendens). ${ }^{31}$ The Model Law covers much less

\footnotetext{
${ }^{28}$ See Pottow, Beyond Carve-Outs, supra note 6, 209. See further Pottow, Procedural Incrementalism, supra note 9.

${ }^{29}$ Reflecting the view of prominent judges in the common law world. See e.g., Sir Peter Millett, CrossBorder Insolvency: The Judicial Approach, 6 INT'L. INSOLV. REV. 99, 108 (1997).

${ }^{30}$ See Clift, The UNCITRAL Model Law, supra note 26, 308. See also Berends, UNCITRAL Model Law, supra note 26, 319 ("A model law is better than an unratified convention. A convention ratified by too few countries is worse than a partially enacted model law."). Unsuccessful attempts have been made in the recent past at the instigation of the International Bar Association to revisit the idea of a global convention at UNCITRAL: see Report of Working Group V (Insolvency Law) on the Work of its Forty-Fourth Session, U.N. Doc. A/CN.9/78 (2013) at paras. 18-19; Goodbye UNCITRAL Model Law; Hello International Insolvency Convention, GLOBAL TURNAROUND, Apr. 2016, at 11 cf. Jenny Clift, UNCITRAL Model Law - alive and well in 43 jurisdictions and counting!, GLOBAL TURNAROUND, May 2016, at 11.

${ }^{31}$ Examples include the EU INSOLVENCY REGULATION, supra note 1; Regulation (EC) No.593/2008 of the European Parliament and of the Council of 17 June 2008 on the law applicable to contractual obligations (Rome I), 2008 O.J. (L.177/6); Regulation (EU) No.1215/2012 of the European Parliament and of the Council of 12 December 2012 on jurisdiction and recognition and enforcement of judgments in civil and commercial matters (recast), 2012 O.J. (L. 351/1); Hague Convention of 15 November 1965 on Jurisdiction, Applicable Law and Recognition of Decrees Relating to Adoptions.
} 
ground. It defines the scope of a foreign proceeding. ${ }^{32}$ It determines when foreign proceedings will be recognized in an enacting state drawing on well-established international jurisdictional standards borrowed from the EU Insolvency Regulation namely, centre of main interests ("COMI") ${ }^{33}$ and establishment ${ }^{34}-$ and provides for streamlined recognition ${ }^{35}$ of foreign main proceedings in the country where the debtor has its COMI and foreign non-main proceedings in countries where the debtor has an establishment, ${ }^{36}$ unless recognition would be "manifestly contrary to public policy" in the country in which recognition is sought. ${ }^{37}$

The Model Law has three other core features. First, it confers direct rights of access to an enacting state's courts on the foreign representative - that is, the party entrusted with the governance of the foreign proceeding who has standing under the Model Law to act as representative of the foreign proceeding ${ }^{38}$ - including the right of the foreign representative to apply for recognition of the foreign proceeding in which they have been appointed..$^{39}$ It also promotes direct process and participatory rights for foreign creditors rooted in a principle of non-discrimination. ${ }^{40}$

\footnotetext{
${ }^{32}$ See MODEL LAW, supra note 4, art 2(a) (“'Foreign proceeding' means a collective judicial or administrative proceeding in a foreign State, including an interim proceeding, pursuant to a law relating to insolvency in which proceeding the assets and affairs of the debtor are subject to control or supervision by a foreign court, for the purpose of reorganization or liquidation."); GUIDE TO ENACTMENT, supra note 4, paras 62-79.

${ }^{33}$ See MODEL LAW, supra note 4, arts. 2(b), 16(3), 17(2)(a); GUIDE TO ENACTMENT, supra note 4, paras. 1, 11, 18, 31, 81-84, 141-44, 145-49, 157-59, 162, 178, 236, 238.

${ }^{34}$ See MODEL LAW, supra note 4, arts. 2(c), 2(f), 16(3), 17(2)(a); GUIDE TO ENACTMENT, paras. 32, 72, 83, 85, 88-90 (noting the EU law derivation of establishment), 156, 160, 225-27, 235

${ }^{35}$ See MODEL LAW, supra note 4, arts. 15-17; GUIDE TO ENACTMENT, supra note 4, paras. 29, 127.

${ }^{36}$ See MODEL LAW, supra note 4, art.17(2); GUIDE TO ENACTMENT, supra note 4, paras.31-32.

${ }^{37}$ See MODEL LAW, supra note 4, art.6; GUIDE TO ENACTMENT, supra note 4, paras.101-104.

${ }^{38}$ See MODEL LAW, supra note 4, art.2(d); GUIDE TO ENACTMENT, supra note 4, paras. 62-64, 86.

${ }^{39}$ On the foreign representative's access and standing rights see MODEL LAW, supra note 4, arts.9-12, 15, 23-24; GUIDE TO ENACTMENT, supra note 4, paras.25-26.

${ }^{40}$ See MODEL LAW, supra note 4, arts.13-14; GUIDE TO ENACTMENT, supra note 4, paras.118-126. See further Pottow, Procedural Incrementalism, supra note 9, 980-82 (flagging the individual notice requirements in art.14) .
} 
Second, it makes provision for the grant of relief in the enacting state to assist the foreign proceeding. Interim relief, pending recognition, is available at the discretion of the court. ${ }^{41}$ Fundamental forms of relief such as a stay of individual enforcement action against the foreign debtor or the debtor's assets and a suspension of the debtor's right to transfer or encumber assets come into effect automatically on recognition of a foreign main proceeding. ${ }^{42}$ Discretionary relief is also available following recognition to both foreign main and foreign non-main proceedings. ${ }^{43}$ The court can use its power to grant discretionary relief to expand the automatic relief applicable on recognition of a main proceeding or to provide relief to a foreign non-main proceeding.

Third, it provides a framework for cooperation and communication, including court-to-court communication, and for coordination of concurrent proceedings relating to the same debtor in more than one country. ${ }^{44}$ This framework, which is not dependent on recognition, provides a legal foundation for the negotiation, use, and court approval of cross-border insolvency protocols as a mechanism for coordinating the various proceedings. ${ }^{45}$

As a pragmatic exercise in the art of the possible, the Model Law is otherwise neutral by design. Its framers believed that neutrality was crucial to achieving the level of buy-in needed to break down procedural barriers and institute a basic international

\footnotetext{
${ }^{41}$ See MODEL LAW, supra note 4, art.19; GUIDE TO ENACTMENT, supra note 4, paras.35-36, 170 ("Article 19 deals with 'urgently needed' relief that may be ordered at the discretion of the court and is available as of the moment of the application for recognition..."), 171-75.

${ }^{42}$ See MODEL LAW, supra note 4, art.20; GUIDE TO ENACTMENT, supra note 4, paras.35-36, 176-188 ("While relief under articles 19 and 21 is discretionary, the effects provided by article 20 are not, for they flow automatically from recognition of the foreign main proceeding.").

${ }^{43}$ See MODEL LAW, supra note 4, art.21; GUIDE TO ENACTMENT, supra note 4, paras. 35-36, 189-195.

${ }^{44}$ See MODEL LAW, supra note 4, arts.25-32; GUIDE TO ENACTMENT, supra note 4, paras. 3, 40-45, 20941. The Model Law in art.25(1) mandates cooperation ("...the court shall cooperate to the maximum extent possible with foreign courts or foreign representatives...") but what such cooperation entails is left openended in the interests of flexibility.

${ }^{45}$ See further U.N. COMM ON INT'L TRADE LAW, PRACTICE GUIDE ON CROSS-BORDER

INSOLVENCY COOPERATION, U.N. Sales No. E.10.V.6 (2010).
} 
architecture that would facilitate swift access to foreign courts for purposes of asset preservation. ${ }^{46}$ The Model Law makes no attempt at substantive unification of insolvency law. It has no uniform choice-of-law rules, and no enumerated rules on recognition and enforcement of foreign insolvency-related judgments, such as foreign discharge or claw back orders. ${ }^{47}$ Much is therefore left to local implementation and local rules.

The Model Law therefore contrasts with the EU Insolvency Regulation - a more complete procedural private international law code forming part of the EU's acquis communautaire, the body of supranational law directly applicable in EU member states by virtue of the EU's founding treaties. ${ }^{48}$ This establishes a reciprocal legal framework containing uniform rules on jurisdiction, applicable law, recognition of insolvency proceedings, and recognition and enforcement of insolvency-related judgments. Importantly, the EU Insolvency Regulation leaves less leeway for divergent local implementation because it directly applies in Member States and its binding,

\footnotetext{
${ }^{46}$ See Berends, UNCITRAL Model Law, supra note 26, 319 (characterizing the Model Law as a "first step"), 321 ("The general idea behind the Model Law is that there are only three things that are important in cross-border insolvency: speed, speed, and more speed... To avoid the dissipation of assets that may result from time-consuming procedures or considerations, the Model Law also provides for a system that enables quick action.").

${ }^{47}$ See id. 321 ("The Model Law does not modify the existing material rules concerning insolvency proceedings in the enacting State. The State effecting the opening of the proceedings does not export the effects it attaches to the insolvency proceeding; the law of the State where the foreign proceeding is recognized determines which effects are given to the proceeding."). See also Clift, Choice of Law, supra note $26,28-30$.

${ }^{48}$ See Treaty on the Functioning of the European Union (Consolidated version 2016), 2016 O.J. (C. 202/01), art. 288. The EU Insolvency Regulation does not apply to Denmark: see EU INSOLVENCY REGULATION, supra note 1, recital 88. On June 23, 2016, the UK's electorate voted to leave the EU in a referendum. Until the UK formally withdraws in accordance with procedures set out in the Treaty on European Union (Consolidated version 2016), 2016 O.J. (C. 202/01), EU law, including the Insolvency Regulation, continues to apply. Although the UK government notified the European Council of its intention to withdraw on March 29, 2017, the manner of the UK's withdrawal and the nature of its future political and legal relationship with the EU is still to be determined. Under Article 50(3) of the Treaty on European Union, the formal date of departure is the date the withdrawal agreement enters into force. This allows for the possibility of transitional arrangements. However, if agreement on terms of withdrawal is not reached, the Treaties will cease to apply in March 2019, two years after the UK's withdrawal notification, unless the European Council agrees to extend the default two-year period.
} 
supranational legal character is further reinforced by the centralized role that the Court of Justice of the European Union plays in its interpretation.

Until it is locally enacted, the Model Law has no binding force. As the uniform text can be modified locally, the Model Law trades off flexibility against certainty ${ }^{49}$ and aims at harmonization by softer, non-binding means. Article 8 promotes harmonized interpretation of Model Law enactments, ${ }^{50}$ thus permitting courts to consider sources beyond the domestic text, and the Guide to Enactment encourages enacting states to be as faithful as possible to the Model Law text when incorporating it into their legal systems. ${ }^{51}$

The Model Law also contains no default reciprocity requirements. ${ }^{52}$ Instead, it favors unilateral commitments to recognition, relief and cooperation as a first move towards a multilateral framework based on what Professor Westbrook describes as "critical mass reciprocity". ${ }^{53}$ The neutrality of the Model Law - especially as regards choice-of-law ${ }^{54}$ - is important because it leaves room for contestation between divergent legal traditions and between stronger and weaker forms of modified universalism, as we will see.

\footnotetext{
${ }^{49}$ See GUIDE TO ENACTMENT, supra note 4, para. 20,

${ }^{50}$ Id. paras. 22, 106-107.

${ }^{51} \mathrm{Id}$. paras. 20-22. There is, however, no institutional mechanism for centralized interpretation, a function that the Court of Justice of the European Union performs in the EU context.

${ }^{52}$ See Keith D. Yamauchi, Should Reciprocity Be a Part of the UNCITRAL Model Cross-Border Insolvency Law, 16 INT. INSOLV. REV. 145 (2007). I pass no comment on the virtues or vices of reciprocity requirements. My point is to contrast the Model Law with the EU Insolvency Regulation which is supranational \& multilateral in character.

${ }^{53}$ See Westbrook, Theory and Pragmatism, supra note 17, 467 (identifying "critical mass reciprocity" as a subset of multilateral reciprocity "sufficient to convince each cooperating state that enough other states have joined in reciprocal relationships to ensure the obtaining of the benefits expected to flow from a particular sort of cooperation."), 488 (discussing "common unilateralism" as a possible way to achieving critical mass reciprocity without the necessity for a treaty).

${ }^{54}$ See GUIDE TO ENACTMENT, supra note 4, paras. 35, 178; Clift, UNCITRAL Model Law, supra note 26, 324 (“...[T] he Model Law adopts a neutral approach, standardizing the effects of recognition...rather than importing the consequences of the foreign law into the insolvency system of the enacting State."); Clift, Choice of Law, supra note 26, 28-30 (outlining how the Model Law's framers, after considering various options, including an applicable "law of the main proceeding" rule, adopted a choice of forum test that was deliberately choice-of-law neutral so that recognizing courts would not be corralled into applying foreign law).
} 


\section{B. The Model Law as an Instrument of Modified Universalism}

There is a scholarly consensus that universalism, characterized as the "administration of multinational insolvencies by a leading court applying a single insolvency law", is the ideal system for managing cross-border insolvencies in a global market setting. ${ }^{55}$ A system of "pure universalism" that combines "unity of insolvency" (a single, exclusive and preclusive insolvency forum in which assets and claims worldwide are administered and resolved) and "universality of insolvency" (a single insolvency law having worldwide effect) has always been considered politically unfeasible. ${ }^{56}$ The universalist ideal in a world of sovereign nation states is a system in which a single main insolvency proceeding is instituted in the debtor's "home" country - the country where the debtor has its COMI - with courts elsewhere assisting the "home" court to accomplish a unitary administration of the worldwide estate under "home" insolvency law. Thus, in the absence of a system of world government, the "ideal" is universality without unity: a dominant "home" court to which ancillary courts elsewhere will defer in order to facilitate centralized, collective administration of estate property and claims. ${ }^{57}$

Normatively, this system of dominant and ancillary courts, rooted in principles of universality and deference, would achieve virtually everything to which universalists aspire. It would replicate transnationally the welfare benefits of domestic insolvency

\footnotetext{
${ }^{55}$ See Westbrook, Global Solution, supra note 11, 2277.

${ }^{56}$ Id. See also LoPucki, Cooperation in International Bankruptcy, supra note 17, 705-706; Adams \& Fincke, Coordinating Cross-Border Bankruptcy, supra note 22, 48. On "unity" and "universality" and their binary opposites "plurality" and "territoriality" (which imply multiple domestic, territorial proceedings administered in accordance with local law), see FLETCHER, INSOLVENCY IN PRIVATE INTERNATIONAL LAW, supra note 27, 11-15.

${ }^{57}$ See Westbrook, National Regulation, supra note 5, 778-79 ("The ideal of universalism is of a single primary bankruptcy proceeding in the debtor's home country, with courts elsewhere acting in an ancillary or supportive role to the primary court, resulting in unitary administration of assets under one bankruptcy law.").
} 
systems by replacing a costly, duplicative, value-destructive international free-for-all with a global market-symmetrical, value maximizing, cost reducing, collective proceeding incorporating a single, efficient claims resolution process that affords similarly situated creditors equal treatment worldwide. It would pull cross-border insolvency law decisively away from territorialism - universalism's polar opposite - an uncoordinated, state-centric default "system" in which each jurisdiction "grabs" and administers locally situated assets in a local insolvency proceeding for the benefit of creditors claiming locally with no regard for what is happening elsewhere. ${ }^{58}$

As an intellectual paradigm, modern universalism (dating from around 1990) has two characteristics. First, it takes globalization for granted and assumes that law's job is to facilitate global markets by making them as legally convergent and frictionless as possible. ${ }^{59}$ It posits a world in which creditor expectations are shaped globally rather than locally and dismisses territorialist concerns about the legitimate expectations of local creditors as a throwback to old notions of vested rights. ${ }^{60}$ In this sense, it represents a

\footnotetext{
${ }^{58}$ In truth, "pure" or "ideal" universalism and wholly unmitigated territorialism are the bookends of a complex spectrum neither of which accords with reality. Territorialists, such as Professor LoPucki, do not support unmitigated territorialism and accept that legal convergence may ultimately create conditions for universalism: see LoPucki, Cooperative Territoriality, supra note 17, 2217. But territorialists worry about the imposition of COMI insolvency law on remote stakeholders and about universalism's incursions into state sovereignty, especially its ramifications for local priority rules that implicate local policy preferences. These worries harbor a further concern that universalism will encourage pernicious forum shopping. Accordingly, territorialists prefer cooperation that accords sovereigns equal dignity over the global hegemony of COMI law: see LoPucki, Cooperation in International Bankruptcy, supra note 17, 709-713, 743, 750; John J. Chung, The New Chapter 15 of the Bankruptcy Code: A Step Towards Erosion of National Sovereignty, 27 NW. J. INT'L \& BUS. 89 (2006).

${ }^{59}$ See e.g. Westbrook, Global Solution, supra note 11, 2277 ("The force that drives us to [the] future is free-market capitalism constrained in the vessel of democratic institutions. One important element in its progress is the fashioning of an international system for managing the financial crises that are one of the free market's inevitable consequences."). See further $i d$. at 2288-92 (discussing how globalization and economic integration drive legal convergence and progress towards universalism).

${ }^{60}$ See id., 2301, 2320-22. The universalist objection is to vested rights as understood in the unilateralist conflicts tradition associated with Currie: see e.g. William S. Dodge, Extraterritoriality and Conflict-ofLaws Theory: An Argument for Judicial Unilateralism, 39 HARV. INT'L. L.J. 101, 110-119 (1998).
} 
strand of thinking, akin to the Whig view of history, ${ }^{61}$ in which the world is progressing towards the perfection of the liberal international order. Second, it is profoundly North American in orientation. In the hands of its leading modern champion, Professor Westbrook, universalism amounts to a globalized version of US federal bankruptcy law a single "meta" law that stays and collectivizes claims arising throughout the US under the non-bankruptcy law of multiple sovereign states with a view to liquidation or reorganization. ${ }^{62}$

To what extent universalism's globalizing, unifying paradigm can hold under the conditions of deglobalization prevailing in the second decade of the twenty first century is an open question. As a theory powerfully associated with liberal internationalism, ${ }^{63}$ it will need rethinking in an era in which the post-World War II liberal international order is withering. ${ }^{64}$ In any event, universalists have long acknowledged that "the ideal remains some distance away." ${ }^{65}$ For now they put their faith in modified universalism, conceived of as an interim, transitional solution - a staging post on the road to universalism - which

\footnotetext{
${ }^{61}$ See generally HERBERT BUTTERFIELD, THE WHIG INTERPRETATION OF HISTORY (1931).

${ }^{62}$ See Westbrook, Global Solution, supra note 11, 2277 ("The only substantive objection is that universalism would too greatly submerge national policies, but experience in the United States and elsewhere demonstrates that a national, market-symmetrical law can largely accommodate local policies. In the same way, an international system could permit considerable play to varying national policies and could enforce them more effectively against multinationals." See further $i d$. at 2286-87 (discussing the establishment of the US bankruptcy system within the US constitutional order).

${ }^{63}$ On the connection between universalism and liberal international relations theory, see Lore Unt, International Relations and International Insolvency Cooperation: Liberalism, Institutionalism, and Transnational Legal Dialogue, 28 LAW \& POL'Y INT'L BUS. 1040 (1997).

${ }^{64}$ No sooner had Francis Fukuyama proclaimed the triumphant universalization of western liberal democracy as the final form of human government in THE END OF HISTORY AND THE LAST MAN (1992), others were sounding the panic bell: see, e.g. Stanley Hoffmann, The Crisis of Liberal Internationalism, FOREIGN POL'Y, Mar. 1, 1995, at 159. Hoffmann was prescient: see id. at 174 ("The formation of a global transnational economy constitutes a triumph of the liberal vision that first appeared in the eighteenth century (when philosophers saw private interests cutting across borders as potential tamers of clashing state passions), but it also provides evidence of the fact that fulfillment of the vision has mounting costs and unexpected consequences.").

${ }^{65}$ See Westbrook, National Regulation, supra note 5, 779.
} 
makes concessions to sovereigntist concerns by accommodating protections for local creditors and state interests.

The modified universalism that universalists generally favor maintains the dominant/ancillary court aspect of the universalist ideal but anticipates pragmatically that states may be unwilling to cede sovereignty over locally situated assets and creditors and reluctant to tolerate outcome differences that would arise were local assets and claims administered under COMI law priority rules rather than local priority rules. Under modified universalism's dominant strain, ${ }^{66}$ the ancillary court is expected to defer to the law applicable in the main proceeding but such deference is not automatic. Ancillary courts retain the ability to evaluate the fairness of the main proceeding and to protect the interests of local creditors. ${ }^{67}$ They may refuse to defer where home country policies are at odds with fundamental local policies: a standard public policy escape route. ${ }^{68}$ But universalists exhort ancillary courts to ignore trivial outcome differences in pursuit of the aggregate welfare benefits of cooperation over time. ${ }^{69}$ On this view, courts have some leeway in determining how or whether they cooperate but the leeway should be narrow.

Supporters of the strain of modified universalism just outlined - call it American modified universalism - conceive of it as the best way to progress towards universalism

\footnotetext{
${ }^{66}$ See Pottow, Beyond Carve-Outs, supra note 6, 203 (referencing the "now-dominant paradigm of modified universalism").

${ }^{67}$ See Westbrook, Global Solution, supra note 11, 2301.

${ }^{68}$ See Pottow, Procedural Incrementalism, supra note 9, 952-53.

${ }^{69}$ The idea is that the aggregate gains to be made from cooperation will offset losses suffered by creditors from outcome differences in individual cases: see Westbrook, Theory and Pragmatism, supra note 17, 46466 (discussing the "Rough Wash" and "Transactional Gain" arguments for universalism). LoPucki objects to this less than Pareto optimal aggregate welfarism: see Cooperative Territoriality, supra note 17, 2218 ("Westbrook's analysis ignores that it is creditors, not nations, that have entitlements in bankruptcy estates. The creditor that goes unpaid because its country surrenders the assets to a foreign court for distribution according to the foreign country's laws is not consoled by the fact that some other creditor of the same nationality received a windfall from that foreign court in another case."). I demur because I doubt that judges whose focus is on the immediate case in hand, rather than on aggregate welfare across a run of cases, can effectively implement such a system absent a clear statutory mandate: see further Section II, infra.
} 
in the absence of an international convention. ${ }^{70}$ Sometimes, they frame modified universalism as a transitional means for laying foundations, through sustained cooperative engagement, for a global convention. ${ }^{71}$ At other times, they view "modified universalism with presumptive deference to COMI law" (as I would characterize it) as a system that will replicate most of the benefits of universalism even in the absence of a convention. The assumption is that if courts are encouraged through international cooperation to "produce results as close to those that would arise from a single proceeding as local law will permit", ${ }^{72}$ modified universalism will create a workable proxy for universalism without the need for a convention. ${ }^{73}$

Commentators generally agree that the Model Law is an instrument that embodies modified universalism ${ }^{74}$ or, at worst, an artful compromise between universalism and

\footnotetext{
${ }^{70}$ See Westbrook, Global Solution, supra note 11, 2302.

${ }^{71} I d$.

${ }^{72} I d$.

${ }^{73}$ I speculate that American advocates of modified universalism know only too well that global private international law conventions, especially conventions that will command widespread (including US) support, have proved historically difficult to achieve. The Hague Conference successfully engineered a Choice of Court Convention and has subsequently revived the idea of a global Judgments Convention. See https://www.hcch.net/en/projects/legislative-projects/judgments. But if past is prologue there are reasons to be pessimistic about the Judgments Project's prospects.

${ }^{74}$ See Westbrook, Chapter 15 at Last, supra note 7, 716; Pottow, Procedural Incrementalism, supra note 9, 963-69 (describing the Model Law as having core universalist features with territorialist caveats); Janger, supra note 17, 824 ("Under a modified universalist regime, the insolvency case is governed from the debtor's...COMI. Assets in multiple jurisdictions are administered... by the local courts, but those courts defer to the main proceeding for administration of the case. This is the approach embodied in the UNCITRAL Model Law on Cross-Border Insolvency..."); Adams \& Fincke, Coordinating Cross-Border Bankruptcy, supra note 22, 61-63 (describing the Model Law as modified universalism with a territorialist foundation); Irit Mevorach, On the Road to Universalism: A Comparative and Empirical Study of the UNCITRAL Model Law on Cross-Border Insolvency, 12 EUR. BUS. ORG. L.R. 517, 520 (2011) ("The Model Law...aim[s] at a 'modified universalism', promoting a regime which allows for opening more than one set of proceedings but also strives for maximum cooperation and a worldwide perspective."); Allan L. Gropper, The Curious Disappearance of Choice of Law as an Issue in Chapter 15 Cases, 9 BROOK. J. CORP. FIN. \& COM. L. 152, 153 (2014) (hereinafter Gropper, Curious Disappearance) (US enactment of the Model Law in Chapter 15 of the Bankruptcy Code described as substituting "the principle of modified universalism for territorial principles that had previously prevailed."); Andrew Dawson, The Problem of Local Methods in Cross-Border Insolvencies, 12 BERKELEY BUS. L.J. 45, 53 (2015) (hereinafter Local Methods) ("The Model Law, adopted in the United States Bankruptcy Code under Chapter 15, embodies the modified universalist approach.”); REINHARD BORK, PRINCIPLES OF CROSS-BORDER INSOLVENCY LAW 26-44 (2016).
} 
territorialism. ${ }^{75}$ It embraces the concept of a dominant main proceeding presumptively entitled to administer the debtor's worldwide insolvency in the jurisdiction where the debtor has its COMI and yet, at the same time, gives courts grounds for not cooperating, or for conditioning their cooperation, having regard to local public policy or stakeholder concerns, while also permitting concurrent, plenary local proceedings. ${ }^{76}$

But its real significance for universalists who subscribe to "modified universalism with presumptive deference to COMI law" lies in the fact that the Model Law's system of recognition and relief is anchored by a choice-of-forum rule - the COMI principle - that can double up as a choice-of-law rule. And so although, as I outlined earlier, the Model Law is choice-of-law neutral, and does not insist that the recognizing court concede the application of main proceeding insolvency law, it adopts as its core the dominant/ancillary court model, and, in theory, permits ancillary courts to behave "universalistically", i.e. by choosing to defer to main proceeding insolvency law. ${ }^{77}$ Universalists therefore regard the Model Law as incrementally advancing a universalist agenda. ${ }^{78}$ They see leeway for courts in Model Law enacting states, to approximate to

\footnotetext{
${ }^{75}$ See Sefa Franken, Cross-Border Insolvency Law: A Comparative Institutional Analysis, 34 OX. J. LEG. STUDIES 97, 98, 116 (suggesting that the Model Law reflects a cooperative territorialist approach).

${ }^{76}$ See Clift, Choice of Law, supra note 26; see also MODEL LAW, supra note 4, arts. 17(2)(a) (recognition of foreign main proceeding based on debtor's COMI); 6 (public policy exception to recognition or relief); 21(2) (ancillary court's power to entrust distribution of assets to foreign representative subject to court being satisfied that interests of local creditors are adequately protected); 22(1) (ancillary court's power to grant or deny relief under art.19 or 21 conditioned on court being satisfied that the interests of creditors and other interested persons, including the debtor, are adequately protected); 28-29 (preserving possibility of full local concurrent proceedings subject to requirements for cooperation and coordination).

77 See Pottow, Procedural Incrementalism, supra note 9, 970-72.

${ }^{78}$ Id., 970. See also Clift, Choice of Law, supra note 26, 33 ("While the Model adopts [a] middle path, at the same time, it is advancing the universalist agenda, recognizing the primacy of one proceeding (the main proceeding), albeit with what might be described as an incremental approach, and fostering greater acceptance of differences."). Universalists promote a similar agenda in relation to corporate groups. See Samuel L. Bufford, Coordination of Insolvency Cases for International Enterprise Groups: A Proposal, 86 AM. BANKR. L.J. 685 (2013).
} 
universalist outcomes wherever possible, and nudge modified universalism towards universalism proper. And they advocate for judges to behave accordingly. ${ }^{79}$

In theory, then, the Model Law is universalism's Trojan horse. Its neutrality should make it palatable for countries to adopt and repeated interactions between enacting states should acclimate courts to cooperation along universalist lines. In time, the presumed entitlement of the COMI court to control the administration of the estate and resolution of claims on a global basis should harden the COMI principle as a choiceof-law as well as a choice-of-forum rule, creating conditions for linear progress towards actualization of the universalist model in the real world. However, as the Model Law's neutrality presents ancillary courts with choices (deference, non-deference, or something in between) but disguises the underlying choice-of-law questions, ${ }^{80}$ it is equally plausible that its middle-of-the-road compromise will yield an uneven distribution of inconsistent decisional outcomes. This is especially so as regards those aspects of the Model Law that confront judges with leeways that involve (implicit) choices between international cooperation and fidelity to hard-wired domestic legal norms or pre-existing domestic conceptions of cooperation that the Model Law - or its local manner of implementation - does not displace. I develop this theme in Sections II and III.

\section{Patterns of Adoption}

To date, forty-six jurisdictions have enacted laws based on the Model Law. ${ }^{81}$ Some regional patterns have emerged, notably the Model Law's wholesale adoption by

\footnotetext{
${ }^{79}$ See Westbrook, Interpretation Internationale, supra note 10.

${ }^{80}$ See Gropper, Curious Disappearance, supra note 74.

${ }^{81}$ See http://www.uncitral.org/uncitral/en/uncitral_texts/insolvency/1997Model_status.html. The jurisdictions are: Australia, Benin, Burkina Faso, Cameroon, Canada, Central African Republic, Chad, Chile, Colombia, Comoros, Côte d'Ivoire, Democratic Republic of the Congo, Dominican Republic,
} 
the Francophone countries that constitute the Organization for the Harmonization of Business Law in Africa (OHADA), and its adoption at different times by the NAFTA countries (Canada, Mexico, and the US), by four countries in the Asia-Pacific region (Australia, Japan, New Zealand, and Singapore), and by three countries in Central and South America (Chile, Colombia, and Mexico). ${ }^{82}$ However, very few EU member states have enacted the Model Law. ${ }^{83}$ Other jurisdictions, such as Israel and Thailand, are considering adoption.

Critics, impatient at the rate of progress since 1997, identify the Model Law's widespread lack of adoption among many significant UNCITRAL and OECD member states as a sign of weakness. ${ }^{84}$ Conversely, adoption by developing countries that do not have high volumes of cross-border cases gives credence to the view that World Bank and International Monetary Fund programs are spreading the Model Law by coercive means. ${ }^{85}$ Model Law enactments also exhibit considerable variation. Some stick closely

Equatorial Guinea, Gabon, Greece, Guinea, Guinea-Bissau, Japan, Kenya, Malawi, Mali, Mauritius, Mexico, Montenegro, New Zealand, Niger, Philippines, Poland, Republic of Korea, Romania, Senegal, Serbia, Seychelles, Singapore, Slovenia, South Africa, Togo, Uganda, United Kingdom (which has separate enactments covering Great Britain and Northern Ireland and is therefore counted as two jurisdictions), United States, Vanuatu, and two British overseas territories, British Virgin Isles and Gibraltar.

${ }^{82}$ Singapore, which is seeking to position itself as the leading restructuring hub in Asia, is the most significant recent adopter. For background see Wee Meng Seng, Lessons for the Development of Singapore's International Insolvency Law, 23 SING. AC L.J. 932, 966 (2011); FINAL REPORT OF THE INSOLVENCY LAW REVIEW COMMITTEE (2013) (Singapore) at 229-43; Kannan Ramesh, Cross-Border Insolvencies: A New Paradigm, speech delivered at the International Association of Insolvency Regulators' Annual Conference and General Meeting, September 6, 2016, http://abli.asia/NEWS-EVENTS/WhatsNew/ID/23 at para.19 (confirming Singapore's commitment to adopting the Model Law).

${ }^{83}$ See Jenny Clift, UNCITRAL Model Law - alive and well in 43 jurisdictions and counting!, GLOBAL TURNAROUND, May 2016, at 10 (suggesting that many EU member states apply the EU Insolvency Regulation's provisions externally and regard the Model Law as unnecessary).

${ }^{84}$ See S. Chandra Mohan, Cross-Border Insolvency Problems: Is the UNCITRAL Model Law the Answer?, 21 INT'L. INSOLV. REV. 199, 207 (2012) (identifying that 91\% of UN members, 82\% of UNCITRAL members, $81 \%$ of EU members, $58 \%$ of the G20, and 5 members of the G8 had not adopted the Model Law). Significant states with large economies that have not formally adopted the Model Law include: Brazil, China, France, Germany, India, Italy, and Russia.

${ }^{85}$ On international institutional support for Model Law adoption as a best practice standard, see id. 206-7. See further, Goodbye UNCITRAL Model Law; Hello International Insolvency Convention, GLOBAL 
to the Model Law text, a practice encouraged by the Guide to Enactment. ${ }^{86}$ Others deviate in various ways reinforcing the impression that the Model Law is a non-binding procedural instrument at best. ${ }^{87}$

D. The Model Law in Practice: Empirical Evidence

Empirical studies on the operation of Model Law enactments published so far have focused mainly on the US's Model Law enactment in chapter 15 of the Bankruptcy Code. ${ }^{88}$ Three US studies considered the whole population of chapter 15 cases up to defined cut off dates, but these studies are already somewhat historic. ${ }^{89} \mathrm{~A}$ fourth study

TURNAROUND, Apr. 2016, at 11 (attributing the OHADA enactments to conditions attached by the World Bank to debt restructuring aid).

${ }^{86}$ See GUIDE TO ENACTMENT, supra note 4, paras.21-22.

${ }^{87}$ See Mohan, supra note 84, 208-15 (outlining various deviations from the Model Law text in local enactments including express reciprocity requirements, wider than contemplated exclusions for banks and financial institutions, wider public policy exceptions, and access restrictions). See also FLETCHER, INSOLVENCY IN PRIVATE INTERNATIONAL LAW, supra note 27, 486 (expressing optimism about the Model Law as a "first-base advance along the arduous path of the journey towards a really worthwhile and effective model of international regulation of cross-border insolvency" but cautioning that " $[t]$ he fact that it is open to a State to enact as much, or as little, of the Model Law as it pleases is likely to be viewed by some as an Achilles' heel of this form of international harmonization."); Kent Anderson, Testing the Model Soft Law Approach to International Harmonisation: A Case-Study Examining the UNCITRAL Model Law on Cross-Border Insolvency, 23 AUS. YEARBOOK OF INT'L LAW 1, 11-14 (2004) (doubting whether Japan has fully implemented the Model Law given deviations from the official text); Andrew Godwin et al, The Inherent Power of Common Law Courts to Provide Assistance in Cross-Border Insolvencies: From Comity to Complexity, 26 INT'L. INSOLV. REV. 5, 35 (2017) (noting Canadian deviations from the Model Law text and acknowledging the variable permutations of local Model Law enactments and interpretive practices).

${ }^{88}$ See Andrew Dawson, Offshore Bankruptcies, 88 NEB. L. REV. 317 (2009); Jeremy Leong, Is Chapter 15 Universalist or Territorialist? Evidence from United States Bankruptcy Cases, 29 WIS. INT'L. L.J 110 (2011); Jay L. Westbrook, An Empirical Study of the Implementation in the United States of the Model Law on Cross-Border Insolvency, 87 AM. BANKR. L.J. 247 (2013).

${ }^{89}$ Dawson's dataset includes all chapter 15 cases filed between Oct. 17, 2005 (when chapter 15 became effective) and Oct. 17, 2008. Leong's dataset includes all chapter 15 cases filed between chapter 15 coming into effect and Jun. 8, 2009 (although he counts cases that were administratively consolidated as a single case). Westbrook's dataset includes all chapter 15 cases filed between chapter 15 coming into effect and Jan. 30, 2012. 
includes cases from eight jurisdictions but confirms the US's dominance of case volumes. ${ }^{90}$

With one important caveat, the studies show that the recognition process under Model Law enactments works smoothly. ${ }^{91}$ Courts grant recognition as a foreign main proceeding in the vast majority of cases. Courts rarely invoke the public policy exception in Article $6 .{ }^{92}$ Moreover, although the Model Law makes no specific provision for corporate groups, ${ }^{93}$ and its recognition standards must be applied entity by entity, the evidence suggests that the Model Law is used with some success to assist foreign group proceedings administratively consolidated in a single jurisdiction. ${ }^{94}$ An unpublished study by Alix Partners, which covers the entire population of chapter 15 cases up to September 2016, confirms the impression that courts grant recognition routinely and swiftly. ${ }^{95}$

The caveat concerns offshore jurisdictions. Courts must recognize a foreign proceeding as a main proceeding if it was commenced where the debtor has its COMI. ${ }^{96}$ While the debtor's registered office is presumptively the COMI, ${ }^{97}$ the registered office

\footnotetext{
${ }^{90}$ See Mevorach, supra note 74. Mevorach's dataset captures case abstracts and decisions up to January 2011 from a variety of databases including UNCITRAL's CLOUT database, Westlaw, LexisNexis and WordLII. 145 out of 195 cases in the dataset were US cases.

${ }^{91}$ See Leong, supra note 88, (recognition granted in 88 out of 94 cases); Westbrook, supra note 88, 254-55 (recognition granted in around 96\% of cases); Mevorach, supra note 74, 533-37 (recognition granted in 186 out of 195 cases with objections raised and litigated in only a handful of cases).

${ }^{92}$ See MODEL LAW, supra note 4, art.6; GUIDE TO ENACTMENT, supra note 4, paras.101-104. Recognition can be refused if it would be "manifestly contrary" to an enacting state's public policy. The use of the qualifier "manifestly" signals that the exception should be restrictively construed.

${ }^{93}$ UNCITRAL has issued legislative guidance on the treatment of enterprise groups in insolvency for national legislatures and is considering amendments to the Model Law to deal specifically with the crossborder insolvency of groups. See UNCITRAL, LEGISLATIVE GUIDE ON INSOLVENCY LAW, PART 3 (2010), http://www.uncitral.org/uncitral/en/uncitral_texts/insolvency/2004Guide.html;

UNCITRALWorking Group V, Facilitating the cross-border insolvency of multinational enterprise groups: draft legislative provisions, October 3, 2016, A/CN.9/WG.V/WP.142 (Note by the UNCITRAL Secretariat).

${ }^{94}$ See Mevorach, supra note 74, 537-43; Westbrook, supra note 88, 265-68.

${ }^{95}$ Presented by Simon Appell at a panel session on the Model Law at the Annual Conference of the International Bar Association in Washington DC on Sep. 20, 2016 (on file with author).

${ }^{96}$ See MODEL LAW, supra note 4, art.17(2)(a).

${ }^{97} I d$. art.16(3).
} 
presumption can be rebutted where the central administration of the debtor, as discerned by creditors, is somewhere other than the corporate domicile. To qualify for recognition as a foreign non-main proceeding, the proceeding must have commenced in a jurisdiction where the debtor has an establishment, meaning "any place of operations where the debtor carries out a non-transitory economic activity with human means and goods or services." 98 The adoption of these formal recognition standards aligned the Model Law with the EU Insolvency Regulation and placed the emphasis on the location of core governance functions and the administration of the debtor's operating business. This had the intended effect of disfavoring offshore domiciled "letterbox" entities that are managed onshore while maintaining only a formal connection with the offshore jurisdiction. ${ }^{99}$ This effect was amplified in US practice by the Bear Stearns decision, ${ }^{100}$ which held that the court must satisfy itself that the recognition standards are met even when no party has objected to recognition. Although the tide has turned back towards offshore jurisdictions in light of more recent case law, which acknowledges that COMI can become lodged in the offshore jurisdiction where an insolvency proceeding is

\footnotetext{
${ }^{98} I d$., arts. 2(f), 17(2)(b).

${ }^{99}$ See Dawson, supra note 88, 328. See also Westbrook, Chapter 15 at Last, supra note 7, 727-28; Westbrook, Global Solution, supra note 11, 2317 ("A naked incorporation in a sun-drenched bank haven would easily fall before proof of the actual center of the business."). Westbrook was a member of the US delegation to UNCITRAL during the period of the Model Law's gestation and was involved in its drafting. He was also the co-drafter of chapter 15

${ }^{100}$ In re Bear Stearns High-Grade Structure Credit Strategies Master Fund, Inc., 374 B.R. 122 (Bankr. S.D.N.Y. 2007), aff'd 389 B.R. 325 (S.D.N.Y. 2008). See Dawson, supra note 88, 336-40 (finding a significant decrease in filings from haven countries after Bear Stearns). See also Westbrook, supra note 88, 254-55, 262-63 (63\% of chapter 15 cases in which foreign main proceeding recognition was denied originated from tax havens). Under section 304, chapter 15's statutory predecessor, the debtor or its foreign representative could file an ancillary petition and seek relief in aid of a foreign proceeding in the US without filing a full bankruptcy case. Relief was discretionary and standards-based and the court was required to exercise its discretion by reference to a series of factors, including comity: see Dawson, supra note 88 , at $325-28$. There were, however, no threshold jurisdictional criteria and so a domiciliary proceeding commenced in a haven jurisdiction was prima facie entitled to seek relief and the main issue was whether relief should be granted.
} 
pending, ${ }^{101}$ the Model Law's emphasis on substantial, rather than formal jurisdictional connections, made it initially less "recognition friendly" for insolvency proceedings of offshore domiciliaries while increasing the prospect that ancillary courts in the country of the corporate domicile would recognize a foreign proceeding of their own domiciliary because its business was being conducted and administered elsewhere. ${ }^{102}$

The Model Law's attempts to harmonize streamlined recognition standards and to steer enacting states away from time consuming idiosyncratic local practices such as exequatur and letters rogatory ${ }^{103}$ have succeeded. And because recognition as a main proceeding carries with it automatic relief, including a stay on individual enforcement, the Model Law has also succeeded in granting foreign representatives access to a basic package of relief. This is an undoubted triumph for soft law. ${ }^{104}$ Predictably, however, the evidence suggests that practice as regards the granting of more extensive discretionary

\footnotetext{
${ }^{101}$ In the Matter of Fairfield Sentry Limited, Morning Mist Holdings Limited et al. v. Kenneth Krys et al., 714 F.3d 127 (2 ${ }^{\text {nd }}$ Cir. 2013), aff'g 440 B.R. 60 (Bankr. S.D.N.Y. 2010), 2011 WL 4357421 (S.D.N.Y. 2011); In re Suntech Power Holdings Co., 520 B.R. 399 (Bankr. S.D.N.Y. 2014). Cf. In re Millenium Global Engineering Credit Master Fund Ltd., 458 B.R. 63 (Bankr. S.D.N.Y. 2011), aff'd 474 B.R. 88, 93 (S.D.N.Y. 2012); GUIDE TO ENACTMENT, supra note 4, paras.157-59. See also 8 COLLIER ON BANKRUPTCY I[ 1517.01 (Alan N. Resnick \& Henry J. Sommer eds., $16^{\text {th }}$ ed.); Jay L. Westbrook, Chapter 15 Comes of Age, in ANNUAL REVIEW OF INSOLVENCY LAW (Sarra ed. 2013) at 185-86. Courts have also accepted that debtors can switch COMIs for purposes of restructuring to offshore as well as onshore jurisdictions before the filing of the recognition petition. See, e.g. In re Ocean Rig UDW Inc., 570 B.R. 687 (Bankr. S.D.N.Y. 2017).

${ }^{102}$ See, e.g. In re Buccaneer Energy Limited, [2014] FCA 711 (Aus.) (Australian court recognizing US chapter 11 proceeding of Australian public company with Australian stock exchange listing on the basis that the center of main interests was in the US); In re 19 Entertainment Limited, [2016] EWHC 1545 (Ch) (UK) (English High Court recognizing US chapter 11 proceeding of UK subsidiary of US group where evidence showed its business and operations were conducted in Los Angeles).

${ }^{103}$ See GUIDE TO ENACTMENT, supra note 4, paras. 7-8.

104 Though, as the US was already accustomed to granting such relief under section 304, success should not be exaggerated. See, e.g. the observations of Judge Barnes in In re Ace Track Co., Ltd., 556 B.R. 887, 897 (Bankr. N.D. Illinois 2016) ("Cynically, it seems that much of the international cooperation that has taken place thereunder would have happened nonetheless under the preexisting framework developed under what was section 304 of the Bankruptcy Code.").
} 
relief is spottier. ${ }^{105}$ Thus, the Model Law is self-fulfilling. Its structure is predictive of the patterns observed in the empirical studies. ${ }^{106}$

That the Model Law is an American-led enterprise is beyond doubt. ${ }^{107}$ US case volumes dwarf those in the other enacting states, as one would expect given America's outsized position in the global economy. The US enacted the Model Law out of a conviction that others would follow America's lead. ${ }^{108}$ By signaling its commitment to the Model Law, and acceptance of some constraints on US jurisdiction over US-based assets and claims, the US sought to encourage other countries to acquiesce in the creation of a multilateral system of coordination, the benefits of which would become apparent over time. But one consequence of an implicit bargaining strategy, in which a dominant state pursues its interests by shaping the character of the international order, is that other countries may resist. The friction between forms and cultures of international insolvency cooperation in the US and the UK, discussed further below in Section III, is one source of resistance to the development of a multilateral system along American universalist lines.

\footnotetext{
${ }^{105}$ Leong found that local assets were remitted for administration in the foreign proceeding in less than $50 \%$ of cases and that unconditional turnover of assets was ordered in only $9.1 \%$ of cases in which recognition was granted and in which there were local creditors. His findings must be treated with some caution - see Westbrook, supra note 88, 260-61 - but they suggest unsurprisingly that ancillary courts tend to qualify relief by reference to local considerations.

106 A view that universalists do not dispute. See Westbrook, Interpretation Internationale, supra note 10, 743 ("Given [the Model Law's] structure, one would expect to see considerable success in achieving recognition and a more mixed bag as to relief granted, which is a fair description of what has happened in the adopting countries.").

${ }^{107}$ A cursory search of Model Law case law on UNCITRAL's CLOUT system provides ample confirmation. See http://www.uncitral.org/uncitral/en/case_law.html.

${ }^{108}$ See Westbrook, Chapter 15 at Last, supra note 7, 726 ("The number one reason for adopting it was to demonstrate the United States commitment to the Model Law and to cooperation and universalism generally, in the hope that our example would encourage other countries to follow."). For legislative history see also NATIONAL BANKRUPTCY REVIEW COMMISSION FINAL REPORT, BANKRUPTCY: THE NEXT TWENTY YEARS, 351-70 (1997); H.R. REP. NO. 190-31, at 105-119 (2005) [hereinafter HOUSE REPORT].
} 


\section{INTERNATIONAL HARMONIZATION AND “GLOCAL” JUDGES}

Where frameworks for coordination of cross-border commercial activity derive from instruments of private international law, domestic courts are in the front line of global governance. ${ }^{109}$ Thus, it is domestic courts that allocate governance authority in cross-border insolvency cases. The decision-making matrix for courts often has a binary quality. Decisions to assume insolvency jurisdiction rather than defer to a foreign court on forum non conveniens grounds, or to grant rather than deny recognition to a foreign insolvency proceeding, or to apply local priority rather than foreign priority rules to the distribution of local assets, or to domesticate rather than resist enforcement of a foreign insolvency court judgment, all affect how governance authority is allocated and exercised among states. ${ }^{110}$

The well-rehearsed "universalism vs. territorialism" debate is concerned with what an appropriate framework for international insolvency cooperation should ideally look like. It is framed theoretically in terms of states' interests on the international plane. Stripped to its basics, it involves arguments about the benefits of states conceding some sovereignty in return for aggregate welfare gains from cooperation. ${ }^{111}$ Thus, the literature focuses on states' incentives to cooperate and/or on how states' incentives may influence the contours of the international framework. ${ }^{112}$

\footnotetext{
${ }^{109}$ See Ralf Michaels, Global Problems in Domestic Courts in THE LAW OF THE FUTURE AND THE FUTURE OF THE LAW (Muller et al eds. 2011) at 165, 173-74.

${ }^{110}$ See Christopher A. Whytock, Domestic Courts and Global Governance, 84 TUL. L. REV. 67 (2009).

${ }^{111}$ See Westbrook, Theory and Pragmatism, supra note 17; LoPucki, Cooperation in International Bankruptcy, supra note 17; LoPucki, Cooperative Territoriality, supra note 17; Franken, supra note 75; Lucian A. Bebchuk, An Economic Analysis of Transnational Bankruptcies, 42 J. LAW ECON. 775 (1999); Andrew T. Guzman, International Bankruptcy: In Defense of Universalism, 98 MICH. L. REV. 2177 (2000).

112 See especially, Westbrook, Theory and Pragmatism, supra note 17; Franken, supra note 75; Frederick Tung, Is International Bankruptcy Possible? 23 MICH. J. INT'L. L. (2001) and Fear of Commitment in International Bankruptcy, 33 GEO. WASH. INT'L L. REV. 555 (2001).
} 
Universalists contend that the benefits of cooperation under their model exceed any costs associated with loss of sovereignty whereas territorialists contend the opposite. As universalism, territorialism, and the plethora of intermediate positions, modified universalism chief among them, have come to permeate legal discourse, they have become convenient frames for talking about judicial decision-making in individual cases. If a judge refuses to remit assets to a main proceeding unless and until the claims of local lien creditors are satisfied, we are tempted to describe the judicial behavior crudely as "territorialist". Conversely, if a judge remits the assets and directs local lien creditors to file their claims in the foreign proceeding, we are tempted to describe the judicial behavior as "universalist". Theorizing about model specifications at a high level of generality has given international insolvency lawyers a conceptual - perhaps even a moral - vocabulary that we now use to talk about individual cases at a "street" level of generality.

In the process, theory has metastasized. Universalism's normatively laden account of how inter-country cooperation should be constructed at an abstract level of generality has morphed into a meta judicial guiding principle. The modified universalist frame of American universalists enlists judges as the change agents who, by crafting approximations of universalist outcomes, will nurture the growth of a universalist system. ${ }^{113}$ But there is a disconnect. Judges are not policymakers operating at the theoretical level of system design. In the common law tradition (my immediate frame of reference as an Anglo-American), they are decision-makers who resolve disputes by deciding the immediate case and controversy in accordance with law and their judicial

\footnotetext{
${ }^{113}$ See infra Section III.D.
} 
oath, having due regard for precedent. ${ }^{114}$ So, while the argument that we should not sacrifice aggregate benefits that could be gained through universalistic cooperation over time on the altar of local creditor interests is a defensible utilitarian position, judges do not operate within this type of frame. ${ }^{115}$ Instead, judges decide whether or not to cooperate in specific instances working within the leeways afforded them by the applicable (local) legal framework.

For us to understand the practical utility of modified universalism as a principle for guiding judicial decision-making, we therefore need to pay attention to judges and their frames of reference and go beyond the accounts of judicial agency that we have in the international insolvency law literature to date. John Pottow, writing insightfully from a universalist perspective on how a sovereign's interests in enforcing its own law will affect its incentives to commit to a universalist system, has made a fine start. ${ }^{116}$ But ultimately (and this is not intended as a criticism - Pottow's purpose, which is primarily theoretical, differs from mine), he conceives of decisions not to cooperate as decisions of "states" without fully drilling down into judicial frames of reference. There is then, as I

\footnotetext{
${ }^{114}$ For a persuasive general account of how theoretical legal scholarship fails to account for the nature of legal phenomenon at what I call the "street level", see Ronald J. Allen \& Ross M. Rosenberg, Legal Phenomena, Knowledge, and Theory: A Cautionary Tale of Hedgehogs and Foxes, 77 CHI.-KENT. L. REV. 683 (2002) esp. at 693 ("Courts at all levels...ignore the theorists, while citing the practitioners. The judges apparently, and not surprisingly, are looking for answers to discrete questions, not solutions grounded in grand theory.").

${ }^{115}$ LoPucki's critique of the twin pillars of Westbrook's universalism ("Transactional Gain" and "Rough Wash") in Cooperative Territoriality, supra note 11 at 2218 is germane: "Westbrook's analysis ignores that it is creditors, not nations, that have entitlements in bankruptcy estates. The creditor that goes unpaid because its country surrenders the assets to a foreign court for distribution according to the foreign country's laws is not consoled by the fact that some other creditor of the same nationality received a windfall from that foreign court in another case." See also John Pottow, Greed and Pride in International Bankruptcy: The Problems and Proposed Solutions to "Local Interests", 104 MICH. L. REV. 1899, 1908 [hereinafter Pottow, Greed and Pride] (elaborating on how local creditors in countries where the ratio of assets to claims is high lose out under universalism). My positivistic-cum-realistic riff on LoPucki is that some judges in the common law tradition will find it difficult to defer to foreign law without explicit statutory command. See infra Section III.

${ }^{116}$ See Pottow, Greed and Pride, supra note 115.
} 
think universalists would acknowledge, a problem that a policy of interstate cooperation driven by state level incentives on the international plane is implemented by domestic courts in individual cases as they arise. ${ }^{117}$

The Model Law presents a commonplace legal transposition problem characterized by interlegality. Its origins are international but it has to be enacted by states to have any legal effect. The source of any legally binding norms is domestic law and the orders of domestic courts made thereunder. In dualist systems, even a convention - which creates interstate rights and obligations on the international plane - is not a source of directly enforceable rights and obligations within domestic law. Accordingly, insofar as the Model Law is a source of international norms, these norms only take effect through transplantation into domestic legal orders. Domestic legislatures plant international seeds in domestic soil. All of this is so well understood as to be banal. It is also a trite comparative lawyer's point that the nature of the soil will affect how (or whether) the seeds grow. ${ }^{118}$

When a state enacts the Model Law, the enacting state is, of course, internalizing Model Law norms. But in a framework that confers discretion on courts in individual cases, a straightforward problem of interlegality is apparent. Two normative orders have a bearing on judicial discretion: the domestic legal order, which both constitutes and constrains the domestic court and serves as its primary source of legal authority; and the normative order of international insolvency cooperation - a non-state order albeit one

\footnotetext{
${ }^{117}$ See id. at 1919 (making the point, albeit with particular reference to former $\S 304$, that modified universalist regimes, can face the difficulty that resolution of "policy-clash problems at the sovereign-state level" is in the hands of decision-makers tasked by law "to conduct analyses at the individual-participant level."). I would go further and say that discretionary decision-making at the individual-participant level across systems is a function, in part, of local legal culture and locally constructed leeways.

${ }^{118}$ See generally DAVID NELKEN \& JOHANNES FEEST, ADAPTING LEGAL CULTURES (2001).
} 
based on international consensus - internalized by the domestic Model Law enactment. Interlegality demands that judges (consciously or unconsciously) navigate the interaction of these normative orders. It is conceivable that Model Law "high generality" cooperative norms (such as a preference for reorganization and value maximization) may push in one direction while the local enacted text, and the wider domestic legal order in which it is embedded, will pull in the opposite direction.

In the event of this kind of "text versus purpose" conflict - which will often present as a suppressed "should the court defer to the 'home' insolvency court/law?" comity-cum-choice-of-law question - judges operate "glocally". The local enactment may well require them to pay attention to the international (global) origin of the Model Law and its legislative purpose and permit them to go beyond the local text for purposes of interpretation (to consider, for example, the Model Law and Guide to Enactment and, via Article 8, foreign court rulings on Model Law provisions). And yet they are still anchored within their domestic system and its path dependencies. ${ }^{119}$ The extent of the porosity between global and local - which courts will determine in applying the domestic enactment over time - will, in turn, determine how the "global" influences the "local" or vice versa. How the interaction plays out will shape the reception of international norms within domestic law. ${ }^{120}$ Interlegality does not presuppose any particular outcome.

\footnotetext{
${ }^{119}$ On the importance of historical institutionalism and path dependency in understanding the evolution of law and policy comparatively see Iain Ramsay, US Exceptionalism, Historical Institutionalism, and the Comparative Study of Consumer Bankruptcy Law, 87 TEMP. L. REV. 947 (2015). See also Oona A. Hathaway, Path Dependence in the Law: The Course and Pattern of Legal Change in a Common Law System, 86 IOWA L. REV. 601 (2001); John Bell, Path Dependence and Legal Development, 87 TUL. L. REV. 787 (2013).

${ }^{120}$ See generally William Twining, Diffusion and Globalization Discourse, 47 HARV. INT'L L.J. 507 (2006) and Normative and Legal Pluralism: A Global Perspective, 20 DUKE J. COMP. \& INT'L. L. 473 (2010). See also TWINING, supra note 20; Ralf Michaels, Global Legal Pluralism, 5 ANNUAL REVIEW OF LAW AND THE SOCIAL SCIENCES 243 (2009); Kaarlo Tuori, Transnational Law: On Legal Hybrids and Legal Perspectivism in TRANSNATIONAL LAW: RETHINKING EUROPEAN LAW AND LEGAL
} 
Normative orders can conflict or they can fuse and accommodate through contestation, coordination, and negotiation, ${ }^{121}$ though accommodation of international norms may depend on questions of national "fit". 122

This question of how domestic courts handle norms that originate from the international order is old hat. There is an extensive literature on the role of national courts in the international legal order, much of it seeking to come to terms with the impact of globalization on Westphalian "black-box" notions of national territorial sovereignty. ${ }^{123} \mathrm{~A}$ related literature explores divergence in national interpretation of international law international conventions in particular. ${ }^{124} \mathrm{~A}$ large subset of this literature is concerned with the domestic reception of public international law in circumstances where international law has not formally become part of domestic law within dualist systems.

THINKING (Maduro et al eds. 2014) (on plural legal orders and interlegality); Michele Graziadei, Comparative Law as the Study of Transplants and Receptions in THE OXFORD HANDBOOK OF COMPARATIVE LAW (Reimann \& Zimmermann eds. 2006) (on how transfer and reception both diffuses and shapes norms); Anthea Roberts, Comparative International Law? The Role of National Courts in Creating and Enforcing International Law, 60 INTL. \& COMP. L. Q. 57 (2011) (on the dual nature of the role of national courts in the creation and enforcement of international law).

${ }^{121}$ Twining, Diffusion and Globalization Discourse, 47 HARV. INT'L L.J. 507 (2006), 513 (“Interlegality suggests interaction between discrete entities, but the interaction is often more like that between waves or clouds or rivulets than between hard, stable entities like rocks or billiard balls."). See also Paul Schiff Berman, Global Legal Pluralism, 80 S. CAL. L.R. 1158 (2007), Federalism and International Law Through the Lens of Legal Pluralism, 73 MO. L. REV. 1151 (2008), and Towards a Jurisprudence of Hybridity, 1 UTAH L.R. 11 (2010); Robert Wai, The Interlegality of Transnational Private Law, 71 LAW \& CONTEMP. PROB. 107 (2008).

${ }^{122}$ See Antoine Hol, Highest Courts and Transnational Interaction, 8 UTRECHT L.R. 1 (2012) (on the tension between consistency in transnational law and internal coherence in domestic legal systems).

${ }^{123}$ See, e.g. Neil Walker, Beyond Boundary Disputes and Basic Grids: Mapping the Global Disorder of Normative Orders, 6 INT'L J. OF CON. L. 373 (2008); John Linarelli, Analytical Jurisprudence and the Concept of Commercial Law, 114 PENN ST. L.R. 129 (2009).

${ }^{124}$ See e.g. Michael F. Sturley, International Uniform Laws in National Courts: The Influence of Domestic Laws in Conflicts of Interpretation, 27 VA. J. INT'L. L. 729 (1987); Michael Joachim Bonell, International Uniform Law in Practice - Or Where the Real Trouble Begins, 38 AM. J. COMP. L. 865 (1990); Larry A. DiMatteo, The Interpretive Turn in International Sales Law: An Analysis of Fifteen Years of CISG Jurisprudence, 24 NW. J. INT'L. \& BUS. 299 (2004); Paul Schiff Berman, The Inevitable Legal Pluralism Within Universal Harmonization Regimes: The Case of the CISG, 2016 UNIF. L. REV. 1 (offering various accounts of the generic problem of divergent judicial interpretation of uniform law among different interpretive communities). 
Nevertheless, it reinforces the point that "glocal" judges have a multifaceted status as domesticators and shapers of international norms. ${ }^{125}$

Faced with the domestic-international hybridity of a Model Law enactment what can we expect "glocal" judges to do? To arrive at an answer we need some basic understanding of their incentives ${ }^{126}$ and how they conceive of their own role, consciously or unconsciously as frontline actors. As regards incentives, we might expect judges to be motivated by a mixture of institutional and personal factors: preservation of judicial independence, fidelity to the law and to their oath, judicial economy (including effective management of cases, dockets, and workload), career progression, and reputation. As regards their role in mediating between the international and domestic planes, "universalism versus territorialism" provides one possible conceptual frame but it is crude and quickly collapses into modified universalism's unspecific "they should cooperate as far as they are able". ${ }^{127}$ Let me make the assumption that most judges will

\footnotetext{
${ }^{125}$ See Roberts, supra note 120, 59-60, 61-64 (discussing how the duality of domestic court decisions creates ambiguity about the actual and appropriate role of national courts and may lead to divergent interpretations of the content of international law due, in part, to national courts having different perceptions of their own role in the reception and application of international law). See also Stephane Beaulac, Thinking Outside the "Westphalian Box": Dualism, Legal Interpretation and the Contextual Argument in THE NEW INTERNATIONAL LAW: AN ANTHOLOGY (Eriksen \& Emberland eds. 2010). ${ }^{126}$ See e.g. LEE EPSTEIN, WILLIAM M. LANDES, \& RICHARD A. POSNER, THE BEHAVIOR OF FEDERAL JUDGES: A THEORETICAL AND EMPIRICAL STUDY OF RATIONAL CHOICE (2013); Renée Cohn Jubelirer, The Behavior of Federal Judges: The "Careerist" In Robes, 97 JUDICATURE 98 (2013). Of course, incentives may differ among judges in the same legal system (e.g. between elected and unelected judges and between life-tenured Article 3 and fixed term Article 1 federal judges in the US) and among judges in different legal systems. My brief sketch of incentives in the text is biased towards the global north, which reflects my priors.

${ }^{127}$ See, e.g. Jay L. Westbrook, Multinational Enterprises in General Default: Chapter 15, the ALI Principles, and the EU Insolvency Regulation, 76 AM. BANKR. L.J. 1, 9 (2002) ("The universalists respond to the pragmatic argument of the territorialists with 'modified universalism'. There is no doubt that national insolvency laws differ greatly, especially as to priority in distribution, and that these differences will continue to exist for some time. Modified universalism responds to this difficulty by proposing a pragmatic development of universalism, moving toward the ultimate goal within the practical limits established by the markets and by local laws at any particular time and place. But to say this position is pragmatic is not to say it lacks principle or direction. On a national legislative level, it presses for less rigid rules for multinational debtors. Under existing laws, it adopts a worldwide perspective that seeks results as close to those achievable under a true universalism as national laws will permit in the circumstances of each case.");
} 
care most deeply about fidelity to the law and the avoidance of time consuming jurisdictional conflicts (economy or, more crudely, docket management). If that assumption holds most of the time, courts will try to give effect to the cooperative spirit of the local enactment having regard to permissible sources (which include the Model Law, the Guide to Enactment, and, via Article 8, foreign court determinations) but they will necessarily pay close attention to the manner of implementation and how the local enactment fits in with, or alters, pre-existing local law. In short, judges may well be outward looking and inclined to cooperate in a broad sense but their response to specific requests for discretionary relief will inevitably be conditioned by locally configured leeways.

The Model Law's combination of choice-of-law neutrality and flexibility (flexibility both in the sense that it can be customized by legislatures to fit the local system and in the sense that it contains general standards and confers judicial discretion), and its built-in concessions to local interests make it susceptible to divergent readings within and across legal systems. These aspects are a feature rather than a bug. Universalists crave bold judges who will appeal to norms of international cooperation embedded in the legislative purposes of Model Law enactments to overcome domestic roadblocks. However, even though Model Law enactments internalize international norms and gesture towards harmonized interpretation through the soft mandate of Article $8,{ }^{128}$ and non-prescriptive practice guidance issued by UNCITRAL,${ }^{129}$ many judges will

Westbrook, National Regulation, supra note 5, 779 (“....advocates of universalism generally support modified universalism, a process in which courts within various countries cooperate to achieve a result as close to the ideal as circumstances and existing domestic law permit.").

${ }^{128}$ The language of Article 8 directs judges to have regard to its international origin and to the need to promote uniformity. I argue in Section III.D., infra, that Article 8 creates a norm of engagement with foreign legal sources but one that is insufficient to displace domestic norms. 
struggle to give such general norms priority over highly specific domestic rules. General norms and soft mandates will not override rules that carry authoritative weight under domestic rules of recognition (in the positivist sense). On issues where the Model Law creates judicial leeway, its choice-of-law neutrality provides no concrete guide to decision. Some judges in some systems may incline towards a universalist reading of the local enactment. Other judges will worry about the lack of any clear normative hierarchy mandating them to prioritize universalist forms of cooperation, especially in systems that traditionally favor application of local bankruptcy law. ${ }^{130}$ It is no surprise, then, that Model Law enactments, as some legal unification skeptics predicted at the outset, yield mixed results from a universalist perspective. ${ }^{131}$

This account of interlegality and the role of domestic courts as receivers and shapers of international norms does not resolve much. But its greater sensitivity to the task confronting judges provides a loose frame for understanding how Model Law enactments are handled, and why practice may diverge within and across legal systems. ${ }^{132}$ Moreover, it implies that interlegality could be resolved in manifold ways

${ }^{129}$ See U.N. COMM ON INT'L TRADE LAW MODEL LAW ON CROSS-BORDER INSOLVENCY: THE JUDICIAL PERSPECTIVE, (updated 2013); U.N. COMM ON INT'L TRADE LAW, PRACTICE GUIDE ON CROSS-BORDER INSOLVENCY COOPERATION, U.N. Sales No. E.10.V.6 (2010).

${ }^{130}$ Contrast, for example, the normative hierarchy in systems of supranational law such as EU law that are constitutionalized in ways that require national courts to give primacy to supranational law over conflicting domestic law. On the primacy of EU law over national law, see Case C-6/64, Costa v. ENEL, [1964] E.C.R. 585 (European Court of Justice). On the problems associated with incomplete hierarchies of normative authority see Walker, supra note 123.

${ }^{131}$ See Paul D. Stephan, The Futility of Unification and Harmonization in International Commercial Law, 39 VA. J. INT'L. L. 743, 785 (1999). Stephan argues in favor of clear and precise choice-of-law rules: id. at 748. Hannah L. Buxbaum, Rethinking International Insolvency: The Neglected Role of Choice-of-Law Rules and Theory, 36 STAN. J. INT'L. L. 23 (2000) also favors an explicit choice-of-law approach. I am skeptical about choice-of-law harmonization unless it is layered on deeper, pre-existing foundations of international cooperation and integration because of the concern that states will not buy in. Even in EU law, the exceptions to the lex concursus dwarf the rule. Because of the trade-offs involved I also think that legislatures have comparative advantages in devising choice-of-law rule and exception frameworks or in codifying existing market trends.

${ }^{132}$ Pottow, Greed and Pride, supra note 115, argues that states have an interest in applying local law for local law's sake independent of whether this confers any quantifiable benefit on private local actors. Hence 
leading to hybridity (approaches that prioritize international norms over domestic norms; approaches that prioritize domestic norms over international norms; various strains in between). The account also illustrates that international insolvency law scholarship needs to pay systematic attention to institutional factors, including local legislative implementation and judicial agency, so as to bridge the gap between its system design theories and the actualization of those theories in practice.

\section{ANGLO-AMERICAN EXPERIENCE WITH MODEL LAW ENACTMENTS}

The Model Law was enacted into US law as chapter 15 of the Bankruptcy Code with effect from October 17, 2005. ${ }^{133}$ The following year, the Model Law was enacted into British law by the Cross-Border Insolvency Regulations 2006 (“CBIR"). ${ }^{134}$ Ostensibly, in transposing the law, both the US and UK stayed close to the Model Law's text in accordance with the Guide to Enactment's recommendation "that States make as few changes as possible in incorporating the Model Law into their legal systems." 135

he distinguishes "greed" (a creditor preference for the highest possible payout) from "pride" (a state's vindication of regulatory sovereignty over assets it can plausibly claim to control). My conception of judging maps somewhat onto Pottow's notion of pride, although I prefer to characterize judicial incentives in terms of local legal culture and felt institutional constraint rather than parochialism. To my mind, judges can hardly be criticized for seeking to be faithful to shared understandings of local legislative intent.

${ }^{133}$ Bankruptcy Abuse Protection and Consumer Protection Act of 2005, Pub. L. No. 109-8 §§ 801, 1501(a) (codified as amended at 11 U.S.C. $\S \S 1501-1532$ (2012)).

${ }^{134}$ S.I. 2006 No. 1030. The CBIR have force in the two jurisdictions in Great Britain, i.e. (i) Scotland and (ii) England and Wales. The Model Law was separately enacted in virtually identical terms in the UK's third constituent jurisdiction, Northern Ireland, by the Cross-Border Insolvency Regulations (Northern Ireland) 2007, S.I. 2007 No. 115 (N.I.) pursuant to Northern Ireland's devolution arrangements.

${ }^{135}$ GUIDE TO ENACTMENT, supra note 4, para.20. On US fidelity to the Model Law text see In re Condor Ins. Ltd., 601 F.3d 319, 322 ( $5^{\text {th }}$ Cir. 2010) (“ “...Chapter 15 closely hewed to the text of the [Model Law]...); Westbrook, Chapter 15 at Last, supra note 7, 720 ("Any departures from the actual text of the Model Law in its official English version were as narrow and limited as possible. In only one or two respects were those departures meant to make any substantive change and those instances were specifically identified."). On UK fidelity to the Model Law text see THE INSOLVENCY SERVICE, IMPLEMENTATION OF UNCITRAL MODEL LAW ON CROSS-BORDER INSOLVENCY IN GREAT BRITAIN (2005) [hereinafter UK CONSULTATION DOCUMENT] at para.21 ("The Model Law is a legislative text that forms the basis of a recommendation to States for incorporation into their national law. When drafting the articles, we have tried to stay as close to the drafting in the Model Law as possible to try and ensure consistency, certainty 
However, this apparent shared fidelity to the Model Law text masks significant differences in the structure, language, and normative underpinnings of US and UK crossborder insolvency law.

The divergence between the systems has two related implications. The first is that subtle differences in local implementation and local context, amplified by "glocal" judging, will reinforce divergence. The second, which grows out of the first, is that Model Law enactments will inevitably germinate local hybrids, reinforced by local legal culture, that present challenges for universalism's harmonization agenda. This section accounts for the divergence and teases out these implications further. What emerges is that the US under chapter 15 takes a unilateral approach to international cooperation that conforms broadly to what I have characterized as a strong, American, version of modified universalism, albeit with some lines of resistance that prioritize the text of local law over the text and purpose of the Model Law. The CBIR, by contrast, is one strand of a "third country" regime within a complex, multi-tiered system of UK cross-border insolvency law in which other elements of the system (the EU Insolvency Regulation and section 426 of the UK's Insolvency Act) have pronounced multilateralist features. "British" modified universalism may be of the same genus as its American counterpart, but it is a different species. And judges have plausibly interpreted the CBIR to protect this species from extinction.

and harmonisation with other States enacting the Model Law and to provide a guide for other States who are considering enacting the law. Our policy has been to try and enact as drafted, which may result in the use of some terms, which may not be standard in British insolvency law."). 
A. Manner of enactment: structural and textual aspects of Anglo-US reception of the Model Law

Both countries signaled that they favored a "copy out" mode of enactment and both countries' enactments acknowledge their international origins while closely tracking the Model Law's core structure and provisions. Nonetheless, there are important differences between chapter 15 and the CBIR. I focus on three in particular: (i) the different structure and contours of US and UK cross-border insolvency law; (ii) the variable emphasis on comity in the enactments; and (iii) the different approaches to implementation of Article 23 of the Model Law which provide a window on divergent Anglo-US responses to the Model Law's choice-of-law neutrality. ${ }^{136}$

1. Single portal (US) versus multiple portals (UK)

The US incorporated the Model Law within the Bankruptcy Code and consciously created a single federal gateway to international insolvency cooperation. The Bankruptcy Code is the sole, exclusive source of, and authority for, US federal judicial assistance of foreign representatives and the bankruptcy courts act as gatekeepers to the US legal system as a whole. ${ }^{137}$ Moreover, the US venue rules prescribe that a chapter 15 case will take place in a single venue. ${ }^{138}$ Thus, the US departed from its practice under section 304 by channeling access to US system-wide cooperation through a single federal bankruptcy court. ${ }^{139}$ The recognition process in chapter 15 is the key that unlocks the door. Once a

\footnotetext{
${ }^{136}$ For other discussions from a UK perspective of divergence in Anglo-US Model Law enactments see Gerard McCormack, COMI and Comity in UK and US Insolvency Law, 128 LAW QUARTERLY REV. 140 (2012); US Exceptionalism and UK Localism? Cross-Border Insolvency in Comparative Perspective, 36 LEGAL STUDIES 136 (2016).

${ }^{137}$ See 11 U.S.C. $\$ \S 1504,1509$; Gilhuly et al, supra note $18,79-80$.

13828 U.S.C. $\S \S 157(\mathrm{a}),(\mathrm{b})(1),(\mathrm{b})(2)(\mathrm{P}), 1410,1412$.

${ }^{139}$ HOUSE REPORT, supra note 108, 110 ("Subsections (b)(2), (b)(3), and (c) [of § 1509] make it clear that chapter 15 is intended to be the exclusive door to ancillary assistance to foreign proceedings. The goal is to concentrate control of these questions in one court... This section concentrates the recognition and
} 
foreign proceeding is recognized in chapter 15 , the foreign representative has standing and authority throughout the US system, including the right to commence a full bankruptcy case under chapter 7 or chapter $11 .{ }^{140}$

The CBIR were enacted as secondary legislation under ministerial powers created by the Insolvency Act 2000. ${ }^{141}$ They cross-reference the Insolvency Act 1986, the UK's primary domestic insolvency law, but are otherwise free standing. They also have a gateway feature - the foreign representative's access to judicial assistance throughout the British legal system is channeled through Chancery Division of the High Court in England and Wales and the Court of Session in Scotland ${ }^{142}$ - but the CBIR are far from being the only source of cross-border insolvency law.

UK cross-border insolvency law has evolved in the manner of a medieval church with new parts being added at various times without any great concern for the architectural unity of the edifice as a whole. The CBIR is the most recent addition to that edifice. This source of cross-border insolvency law co-exists with the common law of judicial assistance (which includes the English doctrine of ancillary winding up), the statutory regime in section 426 of the Insolvency Act 1986, and the EU Insolvency Regulation. I have referred to this elsewhere as a "menu" of different options for foreign

deference process in one United States court, ensures against abuse, and empowers a court that will be fully informed of the current status of all foreign proceedings involving the debtor.").

14011 U.S.C. $\S \S 1509$ (b), 1511, 1512, 1524, 1528. A foreign representative can get access to US courts for narrow purposes without recognition: see 11 U.S.C. 1509(f) (foreign representative's right to collect or recover a claim which is property of the debtor without commencing a case or obtaining recognition under chapter 15). Legislative history characterizes this as a "limited exception to the prior recognition requirement" that allows a foreign representative to collect assets such as account receivables: HOUSE REPORT, supra note 108, 110-11. See also In re Iida, 377 B.R. 243, 258 (B.A.P. $9^{\text {th }}$ Cir. 2007); In re Loy, 380 B.R. 154, 164 (Bankr. E.D. Va. 2007).

${ }^{141}$ Insolvency Act 2000 § 14 (c.39) (UK).

${ }^{142}$ CBIR, reg. 2(1), sch. 1, art. 2. The articles in Schedule 1 of the CBIR correspond numerically to the articles in the Model Law. For ease, hereafter I will cite directly to the articles, e.g. CBIR, art.1. 
representatives. ${ }^{143}$ But it is not an à la carte menu. Indeed, UK cross-border insolvency law is better thought of as being like a building with four rooms in which access to each room depends on the identity of the country where the insolvency proceeding is taking place.

Each one of these cross-border insolvency regimes has discrete parameters of application. The EU Insolvency Regulation applies only where the debtor has its COMI in an EU member state. ${ }^{144}$ Letters of request for assistance under section 426 can only be entertained from the courts of designated countries having jurisdiction that corresponds to UK courts' subject matter jurisdiction in relation to insolvency law. ${ }^{145}$ Section 426 is a "favored nation" regime and the countries designated for special treatment all have some historic connection with the UK. ${ }^{146}$ Significantly, the US is not designated for section 426 purposes.

While discrete, the various regimes are not mutually exclusive. A United States bankruptcy trustee could seek judicial assistance at common law and/or under the CBIR. An Australian or Canadian foreign representative could have recourse to the common law, the CBIR, and/or section 426. But this lack of exclusivity begs questions about the

\footnotetext{
${ }^{143}$ See Adrian Walters, Giving Effect to Foreign Restructuring Plans in Anglo-US Private International Law, 3 NOTT. INSOLV. \& BUS. L. e-J. 375, 390, 391 (2015) [hereinafter Giving Effect to Foreign

Restructuring Plans] and The UNCITRAL Model Law on Cross-Border Insolvency and the UK, 36 COMP. LAW 261 (2015).

${ }^{144}$ See EU INSOLVENCY REGULATION, supra note 1, recital (25).

${ }^{145}$ Insolvency Act 1986 § 426(1), (4), (10), (11) (c.45) (UK).

${ }^{146}$ Insolvency Act $1986 \S 426(1)$ provides for internal cooperation among the constituent jurisdictions of the United Kingdom. Insolvency Act $1986 \S 426(11)$ (a) designates the Channel Islands and the Isle of Man, which are Crown dependencies, as $\S 426$ territories. The following countries or territories are designated by statutory instruments pursuant to delegated legislative powers in $\S 426(11)(b)$ : Anguilla, Australia, the Bahamas, Bermuda, Botswana, British Virgin Islands, Brunei Darussalam, Canada, Cayman Islands, Falkland Islands, Gibraltar, Hong Kong, Republic of Ireland, Malaysia, Montserrat, New Zealand, South Africa, Saint Helena, Turks and Caicos Islands, and Tuvalu. See Cooperation of Insolvency Courts (Designation of Relevant Countries and Territories) Orders of 1986 (S.I. 1986/2123), 1996 (S.I. 1996/253), and 1998 (S.I. 1998/2766). All of these countries and territories have at least one (in some cases more than one) of the following attributes: (i) formerly subject to British rule; (ii) member of the Commonwealth; (iii) British Overseas Territory. All have legal systems that are based on English common law.
} 
interactions between each regime and the overall coherence of the law as a whole. It is clear that the EU Insolvency Regulation applies to the exclusion of the other regimes to cases falling within its scope, ${ }^{147}$ and that the CBIR do not affect the continuing application of the common law and section $426 .{ }^{148}$ How the approach under one regime might affect the approach under the other regimes is left to the courts.

Another way to characterize UK cross-border insolvency law is as a tripartite, semi-hierarchical system that has one set of rules for the EU, a second set of rules for section 426 countries, and a third set of rules, the CBIR and common law, for "third countries", i.e. non-EU, non-426 countries. The EU Insolvency Regulation has express choice-of-law rules that apply the "home" country insolvency law subject to a raft of carve-outs. ${ }^{149}$ Moreover, it is binding supranational law underpinned by treaty and grounded in norms of mutual trust and reciprocity. Section 426(5) of the Insolvency Act empowers the UK court to apply the insolvency law applicable by either the UK court or the requesting court in relation to comparable matters falling within its jurisdiction. ${ }^{150}$ Section 426 is also a reciprocity-based regime with what amounts to a system accreditation feature. The countries designated by statutory instrument are countries that

\footnotetext{
${ }^{147}$ This is the effect of the European Communities Act $1972 \S \S 2(1),(4), 3(1)$ combined with the doctrine of EU law primacy developed by the Court of Justice of the European Union. See Case C-6/64, Costa v. ENEL, [1964] E.C.R. 585 (European Court of Justice); Case 11/70, Internationale Handelsgesellschaft mbH v. Einfuhr- und Vorratsstelle für Getreide und Futtermittel, [1970] E.C.R. 1125 (European Court of Justice); Case 106/77, Amministrazione delle Finanze dello Stato v. Simmenthal SpA, [1978] E.C.R. 629 (European Court of Justice); Regina v. Secretary of State for Transport, Ex parte Factortame Ltd. (No. 2), [1991] 1 A.C. 603, 658G-659C, (European Court of Justice and UK House of Lords). See also CBIR, art. 3.

${ }^{148}$ CBIR, art. 7 (not precluding court from providing assistance under other laws of Great Britain); UK CONSULTATION DOCUMENT, supra note 135, paras. 40-43.

${ }^{149}$ See EU INSOLVENCY REGULATION, supra note 1, arts. 7-18, 35. The opening of secondary proceedings based on an establishment also triggers an exception to the main proceeding choice-of-law rule as regards assets situated within the territorial scope of the secondary proceedings. $I d$, arts. 7, 34-35.

${ }^{150}$ Insolvency Act $1986 \S 426(5)$ (c.45) (UK). The willingness of the UK bench and bar to use the $\S 426$ jurisdiction creatively is illustrated by cases such as In re Tambrook Jersey Ltd, [2013] EWCA Civ 576, [2014] Ch 252.
} 
the UK's executive branch has determined will afford the same favorable treatment to requests for assistance from UK courts as UK courts afford to courts in designated countries. It is no coincidence that section 426 countries are all from the British common law world. The historic relationships between the legal systems of the UK and the section 426 countries provide the basic foundation for a reciprocal approach. Section 426 may appear unilateral insofar as it mandates the UK court to assist a court of corresponding jurisdiction in a designated country. But the statutory mandate is underpinned by a system of accreditation in which the executive and legislative branches pre-determine which countries qualify for assistance based on a guarantee of reciprocal treatment.

In the UK, then, the CBIR and the common law together constitute a body of cross-border insolvency law that applies to requests for assistance originating from nonEU, non-426 "third countries". The CBIR upgraded but did not fully codify this "third country" regime. The common law therefore continues to apply and the courts are left to determine how the CBIR and common law should interact. ${ }^{151}$ Moreover, the CBIR, like US chapter 15, are unilateral in character. Thus, under the CBIR a UK court is bound to recognize a foreign main proceeding if it meets the eligibility criteria for recognition regardless of whether the foreign court would recognize a UK proceeding, subject only to the public policy exception. This matters because it means that the CBIR differ normatively from the two other legislative regimes. By contrast, the EU and section 426 regimes are underpinned by strong reciprocity norms generated through pre-existing inter-country legal and structural relationships of various kinds.

\footnotetext{
${ }^{151}$ For example, Parliament did not address the relationship between the "third country" cross-border insolvency regime and the statutory and common law rules on recognition and enforcement of judgments in ordinary civil litigation when it enacted the CBIR. See infra discussion of Rubin in Section III.C.2.b.
} 
2. Textual commitment to comity (US) versus textual silence on comity (UK)

The US version of the Model Law in chapter 15 expresses a clear statutory commitment to comity whereas the CBIR, consistent with the text of the Model Law, make no mention of comity. Take, for example, the manner in which the two countries have enacted Article 9 of the Model Law. The CBIR tracks the single sentence of Article 9 verbatim: "A foreign representative is entitled to apply directly to a court in Great Britain." However, section 1509 of the Bankruptcy Code creates a system of access that, subject to recognition, confers broad entitlements on the foreign representative including, in section 1509(b)(3) an express entitlement to "comity or cooperation." The U.S.'s idiosyncratic enactment of Article 7 in section 1507 also requires courts, among other things, to act "consistent with principles of comity" in granting additional assistance to foreign representatives. Legislative history and subsequent chapter 15 jurisprudence indicate that, subject to the requirement of recognition, the US sought to preserve established forms of relief that courts had granted under section 304 guided by principles of comity. ${ }^{152}$

The difference is subtle. It does not mean that the UK pays no attention to comity, a well-established common law doctrine. ${ }^{153}$ But in the UK's statutory edifice, which as

\footnotetext{
${ }^{152}$ See HOUSE REPORT, supra note 108, 109, 116; In re Atlas Shipping A/S, 404 B.R. 726, 738-739 (Bankr. S.D.N.Y. 2009) (“...[M] any of the principles underlying section 304 remain in effect under chapter 15. Significantly, chapter 15 specifically contemplates that the court should be guided by principles of comity and cooperation with foreign courts in deciding whether to grant the foreign representative additional post-recognition relief. This is evidenced by the pervasiveness with which comity appears in chapter 15's provisions...In short, while chapter 15 replaced section 304 and provided a more structured framework for recognizing foreign proceedings, Congress specifically granted courts discretion to fashion appropriate post-recognition relief, consistent with principles underlying section 304."); In re Condor Ins. Ltd., 601 F.3d 319, 328 ( $5^{\text {th }}$ Cir. 2010) ("Congress intended that case law under section 304 apply unless contradicted by Chapter 15."); Gilhuly et al, supra note 18, 53-56.

${ }^{153}$ See Lawrence Collins, Comity in Modern Private International Law in REFORM AND DEVELOPMENT OF PRIVATE INTERNATIONAL LAW (J.J. Fawcett ed. 2002) 89; Adrian Briggs, The Principle of Comity in Private International Law, 354 RECUEIL DES COURS: COLLECTED COURSES OF THE HAGUE ACADEMY OF INTERNATIONAL LAW 65 (2012).
} 
outlined above also includes two reciprocity-based legislative regimes, there is no reference to comity, whereas it is carried over from prior US law and embedded in US chapter 15. There is no question that UK courts could make use of the doctrine to flesh out Model Law principles of cooperation. ${ }^{154}$ However, as much ground is now occupied by statutory schemes of one sort or another, comity in the UK is a residuum. The variance in emphasis on comity in the UK and US Model Law enactments therefore matters. In the US scheme it is an anchor principle that animates a single body of cross-border insolvency law. ${ }^{155}$ In the UK scheme it is a common law footnote ${ }^{156}$ to a complex body of mainly statutory law much of which rests on deep foundations of international cooperation based on treaties or other reciprocal ties.

3. The great divide: Articles 23, 21, and divergent responses to choice-of-law neutrality

The US enactment of Article 23 is exceptional and the difference between the US approach and that of other countries, including the UK, is symptomatic of a wider structural divergence between US and UK conceptions of modified universalism and of

\footnotetext{
${ }^{154}$ Indeed, UNCITRAL hoped that the principles of cooperation in Articles 25-27 of the Model Law would provide a statutory foundation upon which comity could operate more concretely in cross-border insolvencies in countries where the doctrine is used as a legal basis for international cooperation. See GUIDE TO ENACTMENT, supra note 4, para.214. ${ }^{155}$ See Martin \& Speckhart, CHAPTER 15 FOR FOREIGN DEBTORS, supra note 18, 140-41 (on the pervasiveness of comity in chapter 15). See also In re Vitro S.A.B. de C.V., 701 F.3d 1031 ( $5^{\text {th }}$ Cir. 2012) at 1043 ("[c]entral to Chapter 15 is comity..."), 1044 ("[w]ithin the context of Chapter 15... [comity] is raised to a principal objective"), 1045, 1047, 1053 (comity described as a "central tenet" of chapter 15; reference also to chapter 15's "heavy emphasis on comity"); In re Atlas Shipping A/S, 404 B.R. 726, 738 (Bankr. S.D.N.Y. 2009) ("“o]nce a case is recognized as a foreign proceeding, chapter 15 specifically contemplates that the court will exercise its discretion consistent with principles of comity"). Comity is acknowledged to be a foundational principle of American private international law. See Joel R. Paul, The Transformation of International Comity, 71 LAW \& CONTEMP. PROB. 19 (2008); Donald Earl Childress III, Comity as Conflict: Resituating International Comity as Conflict of Laws, 44 U.C. DAVIS L. REV. 11 (2010); William S. Dodge, International Comity in American Law, 115 COLUM. L. REV. 1 (2015).

${ }^{156}$ On English dismissiveness of comity as an independent basis for judicial decision in the realm of private international law see Collins, supra note 153, 91-94; Briggs, supra note 153, 80-81.
} 
the role of a local ancillary insolvency proceeding. Article 23 provides that on recognition of a foreign proceeding, the foreign representative has standing to initiate avoidance actions available under local law to a person or body administering a reorganization or liquidation. UNCITRAL had in mind the suite of avoidance powers that insolvency laws commonly grant to trustees to enable them to set aside pre-insolvency transactions that are detrimental to creditors such as unfair preferences or fraudulent transfers.

The CBIR enact Article 23 as written and add modifications dealing primarily with applicable claw back periods to ensure that Article 23 actions mesh properly with the UK Insolvency Act avoiding powers regime. Thus, the CBIR track the Model Law in permitting the foreign representative to pursue statutory avoidance actions that under local law can usually only be pursued by a local officeholder in a local insolvency proceeding. ${ }^{157}$

In stark contrast, the US version of Article 23 in section 1523 of the Code confers standing on the foreign representative of a recognized foreign proceeding to initiate avoidance actions but only in a full bankruptcy case under chapter 7 or 11 . Accordingly, section 1521(a)(7) precludes the court from granting relief under the main Code avoiding powers as discretionary relief. Thus, a foreign representative must seek recognition under chapter 15 and then commence an involuntary bankruptcy case under chapter 7 or 11 of the Bankruptcy Code pursuant to section 303(b)(4) in order to make use of US avoiding powers. This approach was born of concerns raised by the US delegation to UNCITRAL that the Model Law's limited grant of standing left complex questions of appropriate

${ }^{157}$ See GUIDE TO ENACTMENT, supra note 4, paras. 201, 203. 
forum and choice-of-law entirely at large ${ }^{158}$ and reflects the strongly held US view that avoiding powers are so integral a part of a insolvency law's distributional scheme that avoidance and distributional rules should derive from the same system of law. ${ }^{159}$

At first blush, the difference appears slight. All Article 23 does is confer procedural standing on the foreign representative. It is choice-of-law neutral and therefore neutral as to the foreign representative's substantive rights. ${ }^{160}$ Article 23 of the CBIR would not preclude a UK court from denying a foreign representative relief under English avoiding powers on English choice-of-law grounds. But if we scratch the surface, the difference over Article 23 points to a more fundamental difference in the choice-oflaw orientation of US and UK cross-border insolvency law in practice.

The Model Law was drafted on the basis of an agreed principle that recognition should have its own effects and should not directly import the consequences of foreign law into the local insolvency system. ${ }^{161}$ Choice-of-law neutrality is fundamental to the design - a feature not a bug. It implements a legislative compromise that perpetuates the divergent viewpoints on choice-of-law that made the compromise necessary in the first place. The leeway the Model Law affords countries to prevent infiltration of foreign law from legal systems in which they may not have full confidence is one of its major selling points. ${ }^{162}$ The possibility of determining the effects of recognition by reference to foreign law, local law or, akin to section 426(5) of the UK Insolvency Act, in accordance with

\footnotetext{
${ }^{158}$ HOUSE REPORT, supra note 108, 116.

${ }^{159}$ In re Condor Ins. Ltd., 601 F.3d 319, 323-327 (5 ${ }^{\text {th }}$ Cir. 2010); Jay L. Westbrook, Choice of Avoidance Law in Global Insolvencies, 17 BROOK. J. INT'L. L. 499 (1991).

${ }^{160}$ GUIDE TO ENACTMENT, supra note 4, para.201; In re Condor Ins. Ltd., 601 F.3d 319, 323-324, 326327 ( $5^{\text {th }}$ Cir. 2010).

${ }^{161}$ GUIDE TO ENACTMENT, supra note 4, paras. 35, 178.

162 See Zoltán Fábok, International Insolvency Law in the New Hungarian PIL Code, https://papers.ssrn.com/sol3/papers.cfm?abstract_id=2919047 at 5.4.
} 
either foreign or local law, was canvassed at UNCITRAL but rejected. ${ }^{163}$ UNCITRAL decided instead to include a short list of autonomous effects in Article 20, designed to provide immediate protection for locally situated assets, which would be triggered automatically by recognition of a foreign main proceeding, while giving courts leeway in Article 21 to grant additional discretionary relief. ${ }^{164}$ Taken as a package of relief measures, Articles 20, 21 and 23 thus contain no express choice-of-law rules.

Leeways inevitably permit a range of possible decisional outcomes. One effect of choice-of-law neutrality is that it suppresses choice-of-law analysis even where the question before the court has choice-of-law implications. ${ }^{165}$ Another effect is that it leaves judges to construe the local enactment by reference to their sense of the local legal framework as a whole. Courts could choose to apply the law of the foreign proceeding as a default choice-of-law rule. ${ }^{166}$ But it does not necessarily follow. Faced with choice-oflaw neutrality, "glocal" judges could equally well look to local law, including local private international law, and local legal tradition for clues. And, in the UK's complex body of cross-border insolvency law, there are mixed choice-of-law messages that make narrow readings of parliamentary intent entirely plausible.

As outlined above in Section III.A.1, the EU and section 426 regimes contain express choice-of-law rules that either mandate application of foreign law subject to carve-outs or permit reference to foreign law. Significantly, however, the tradition in the English common law is for assistance to the foreign representative to be provided either

\footnotetext{
163 See Clift, Choice of Law, supra note 26, 28-30.

${ }^{164}$ See id.

165 See Gropper, Curious Disappearance, supra note 74.

166 See id., 160-64, 178-79.
} 
through the mechanism of an ancillary winding $\mathrm{up}^{167}$ or otherwise by reference to the domestic law that would apply were a local insolvency proceeding to be commenced. ${ }^{168}$ One structural question in UK law therefore is how far does the Model Law alter the preexisting common law position. The CBIR's enactment of Article 23 suggests that one plausible answer is "not much." The UK's Article 23 cleaves to the tradition that the UK courts provide assistance to a foreign representative under domestic law through an ancillary English insolvency proceeding while relaxing the requirement for the foreign representative to commence a full UK parallel proceeding in order to gain access to UK avoiding powers. That tradition is further exemplified by the language of Article 21(1) $(\mathrm{g})$ of the CBIR which, read together with the opening sentence of Article 21, states that "the court may...grant any appropriate relief, including...granting any additional relief that may be available to a British insolvency officeholder under the law of Great Britain...”. In the British common law world, the question of whether, and to what extent, a local court will grant relief to a foreign representative by reference to foreign law is far from settled. ${ }^{169}$

\footnotetext{
${ }^{167}$ See Phillip St. J. Smart, International Insolvency: Ancillary Winding Up and the Foreign Corporation, 39 INT'L \& COMP. L.Q. 827 (1990); Andrew Godwin et al, The Inherent Power of Common Law Courts to Provide Assistance in Cross-Border Insolvencies: From Comity to Complexity, 26 INT'L. INSOLV. REV. 5, 12-13 (2017).

${ }^{168}$ See FLETCHER, INSOLVENCY IN PRIVATE INTERNATIONAL LAW, supra note 27, 185-88, especially at 187 ("The powerful grip of the lex fori upon the main structure of the insolvency process is seemingly unshakeable.).

${ }^{169}$ Even in Cambridge Gas Transport Corp v. The Official Committee of Unsecured Creditors of Navigator Holdings plc, [2006] UKPC 26, [2007] 1 A.C. 508, [22], the high watermark of judicial support for universalism in the UK, Lord Hoffmann doubted whether common law assistance, as distinct from assistance under $\$ 426$, "could take the form of applying provisions of the foreign insolvency law which form no part of the domestic system." See further Justice Steven Rares, Consistency and Conflict - CrossBorder Insolvency, [2015] FED. J. SCHOL. 14 at para. 3 ("However, the legal basis on, and extent to, which the Court of the forum will depart from its local law in co-operating with the law of an insolvent's domicile or centre of main interests is not settled...") (Justice Rares is a judge in the Federal Court of Australia). See also Picard v. Primeo, Cayman Islands Court of Appeal, April 16, 2014 (court finding statutory authority to apply Cayman transaction avoidance provisions but not foreign avoidance provisions).
} 
B. Normative continuities and discontinuities in the Anglo-US reception of the Model Law: a summary

The structural differences in the US and UK enactments reflect subtle normative differences. The US has a single federal body of cross-border insolvency law in chapter 15 animated by comity. There is normative continuity with former section 304 , including some willingness among judges to grant relief to foreign representatives by reference to foreign law and thus some inclination to resolve the Model Law's choice-of-law neutrality in favor of foreign law that is in keeping with a strong version of modified universalism. ${ }^{170}$ Comity is channeled through the statute and subjected to various statutory constraints - the threshold requirements for recognition in sections 1515-1517, the public policy exception in section 1506, and the concept of sufficient protection in sections $1521-1522 .{ }^{171}$ In embracing the Model Law, the US has signaled that it will act unilaterally in the hope that other countries will follow suit and so engender a multilateral approach to international insolvency cooperation by means other than a convention.

By contrast, UK cross-border insolvency law lacks a unitary approach. The UK currently has four cross-border insolvency regimes, two of which (the EU Insolvency Regulation and section 426) are grounded in pre-existing legal orderings ${ }^{172}$ that have strong normative foundations of mutual recognition and reciprocity. The remaining two -

\footnotetext{
170 Though as Allan Gropper points out chapter 15 does constrain the US court's authority to enforce the lex concursus by the requirements in $\S \S 1521$ (b) and 1522(a) that the court be satisfied that parties in interest are sufficiently protected and by the enumerated factors conditioning a grant of additional assistance in $\S 1507$ : see Gropper, Curious Disappearance, supra note 74, 163-76. See also Clift, Choice of Law, supra note 26, 26-31 (characterizing the COMI test as a choice of forum rule that encourages a degree of deference to the foreign law of the main insolvency proceeding "... qualified by the public policy exception of article 6 , the requirement to consider whether the interests of local creditors are adequately protected under article 21(2), and by the provisions of articles 28 and 29 that preserve the pre-eminence of local proceedings over any foreign proceeding...").

${ }^{171} I d$.

${ }^{172}$ Rubin v. Eurofinance SA; New Cap Insurance Corpn Ltd v. Grant, [2012] UKSC 46, [2013] 1 A.C. 236, [25] (per Lord Collins: "Consequently, there are four main methods under English law for assisting insolvency proceedings in other jurisdictions, two of which are part of regionally or internationally agreed schemes.").
} 
the CBIR and the common law - comprise the law applicable to requests for judicial assistance emanating from foreign representatives in third countries. The orientation of the CBIR - as reflected in the UK's enactment of Article 23 and Article 21(1)(g) - is outward looking and yet rooted in the tradition of the common law ancillary winding up in which UK courts will grant assistance insofar as it would be available in an English insolvency proceeding under English law. Thus, the inclination of the UK's third country regime is to resolve the Model Law's choice-of-law neutrality by defaulting to English law and mimicking the effects of a local parallel ancillary insolvency proceeding. Moreover, the structure of UK cross-border insolvency law as a whole inclines courts towards textual rather than policy or system oriented readings of the CBIR.

C. "Glocal" judges and the Model Law

1. "Glocal" judging in the US

The prevalence of comity in US foreign relations law ${ }^{173}$ and cross-border insolvency law, and the continuity between former section 304 and chapter 15, inclines the US towards an unarticulated but functional universalist choice-of-law rule. This is evident in the tendency of US courts to give effect to foreign moratoria ${ }^{174}$ and discharge injunctions ${ }^{175}$ and to permit actions in the US under foreign avoiding powers ${ }^{176}$ subject

\footnotetext{
173 See William S. Dodge, International Comity in American Law, 115 COLUM. L. REV. 1 (2015).

${ }^{174}$ See In re Sanjel (USA) Inc., 2016 WL 4427075 (Bankr. W.D. Texas, 2016) (recognition order giving effect to stay in Canadian foreign proceedings pursuant to 11 U.S.C. $§ 1521$ (a)(1)).

${ }^{175}$ See, e.g., In re Avanti Communications Group Plc, 582 B.R. 603, 605 (Bankr. S.D.N.Y. 2018) ("Recognition and enforcement of schemes of arrangement sanctioned by UK courts has become commonplace in chapter 15 cases..."); In re Energy Coal S.P.A., 582 B.R. 619 (Bankr. D. Delaware, 2018) (injunction in support of restructuring plan following recognition of Italian concordato preventivo). See also Walters, Giving Effect to Foreign Restructuring Plans, supra note 143 (noting at 390 n.72 continuity in US practice traceable back to the Supreme Court decision in Canada Southern Railway Co. v. Gebhard, 109 U.S. 527 (1883)).

${ }^{176}$ See In re Atlas Shipping A/S, 404 B.R. 726, 744 (Bankr. S.D.N.Y. 2009); In re Condor Ins. Ltd., 601 F.3d 319 (5 $5^{\text {th }}$ Cir. 2010); In re Hellas Telecommunications (Luxembourg) II SCA, 535 B.R. 543 (Bankr. S.D.N.Y. 2015).
} 
only to the public policy exception in section 1506 and other conditioning provisions in chapter 15. It is evident too in section 1521(a)(7)'s bar on foreign representative's having access to US avoiding powers. An implicit assumption is that the law of the foreign proceeding should provide the starting point in the absence of express contrary stipulation. So while section 1520 defines the automatic effects of recognition by reference to US law, US courts have extended the scope of the automatic stay by giving US effect to the foreign law stay in the exercise of their discretion under section 1521(a)(1). ${ }^{177}$ Relatedly, in In re Condor Insurance Ltd, the Fifth Circuit inferred from the purpose, structure, and international origins of chapter 15 that by denying foreign representatives standing to sue under US avoiding powers in sections 1521(a)(7) and section 1523, Congress did not intend to prevent US courts from applying the avoidance law of the foreign proceeding. ${ }^{178}$ Thus, the court's authority in section 1521 (a) to grant "any appropriate relief" was sufficiently wide to permit a foreign representative from Saint Kitts and Nevis to pursue an avoidance action in the US under Nevis law.

US courts have also routinely given effect in the US to the foreign law effects of foreign reorganization plans thus binding parties subject to US jurisdiction without any need for confirmation of a parallel chapter 11 plan. ${ }^{179}$ In so doing, US courts have endorsed features of foreign plans, such as non-party releases, that would likely be

\footnotetext{
177 See, e.g., In re Sanjel (USA) Inc., 2016 WL 4427075 (Bankr. W.D. Texas, 2016); In re Daebo International Shipping Co., Ltd., 543 B.R. 47 (Bankr. S.D.N.Y. 2015); Collins v. Oilsands Quest Inc., 484 B.R. 593 (S.D.N.Y. 2012).

${ }^{178} 601$ F.3d 319, 324-328 ( $5^{\text {th }}$ Cir. 2010). This willingness to apply foreign law appears to reflect practice under the prior law in 11 U.S.C. \$304. See e.g. In re Board of Directors of Multicanal, S.A. 314 B.R. 486 (Bankr. S.D.N.Y. 2004) (court recognizing and enforcing Argentine restructuring plan and dismissing involuntary chapter 11 case).

${ }^{179}$ See Walters, Giving Effect to Foreign Restructuring Plans, supra note 143.
} 
unacceptable in domestic chapter 11 reorganization proceedings. ${ }^{180}$ Foreign plans emanating from sister common law jurisdictions, notably Canada and the UK, have received particularly favorable treatment. These include plans that modify or discharge New York law governed obligations. ${ }^{181}$ Viewed from the other side of the Atlantic, US practice in all these instances exemplifies American exceptionalism. ${ }^{182}$ No other Model Law country, apart perhaps from Canada, ${ }^{183}$ has taken such a comity-driven, protouniversalist approach.

US courts do not unhesitatingly apply foreign insolvency law in chapter 15 cases. Indeed, it is important to point out that chapter 15 petitions are frequently uncontested and so result in what might be described as functionally universalist applications of the Model Law. But even in contested cases where US courts have declined to apply foreign law, they have used tempering concepts within the statute itself - such as the requirement that the court may grant discretionary relief only if the interests of creditors and other entities are sufficiently protected - to frame their decision. This is evident from the decisions in two well-known and controversial cases, Qimonda ${ }^{184}$ and Vitro. ${ }^{185}$

In Qimonda the Fourth Circuit prevented a German foreign representative from unilaterally terminating the debtor's licenses of its US patents, a course open to him

\footnotetext{
${ }^{180}$ See In re Metcalfe \& Mansfield Alternative Investments, 421 B.R. 685 (Bankr. S.D.N.Y. 2010); In re Sino-Forest Corporation, 501 B.R. 655, (Bankr. S.D.N.Y. 2013); In re Avanti Communications Group Plc, 582 B.R. 603, 605 (Bankr. S.D.N.Y. 2018).

${ }^{181}$ Under current UK law, a US plan purporting to discharge English law governed obligations, by contrast, would not be given effect in the UK. A parallel proceeding and UK plan would be necessary to achieve the objective of a binding discharge in both countries. See Walters, Giving Effect to Foreign Restructuring Plans, supra note 143. The UK is not alone. This is the position in some Asian jurisdictions. See Min Han, Recognition of Insolvency Effects of a Foreign Insolvency Proceeding: Focusing on the Effect of Discharge in MURUGA P. RAMASWAMY \& JOÃO RIBEIRO, TRADE DEVELOPMENT THROUGH HARMONIZATION OF COMMERCIAL LAW 345 (2015).

182 Gerard McCormack, US Exceptionalism and UK Localism? Cross-Border Insolvency in Comparative Perspective, 36 LEGAL STUDIES 136, 152-154, 160 (2016).

183 See Westbrook, Interpretation Internationale, supra note 10, 745.

184 Jaffé v. Samsung Electronics Company, Limited, 737 F.3d 14 (4 ${ }^{\text {th }}$ Cir. 2013).

${ }^{185}$ In re Vitro S.A.B. de CV, 701 F.3d 1031 (5 ${ }^{\text {th }}$ Cir. 2012).
} 
under German insolvency law. Holding that the sufficient protection standard in section 1522(a) required a balancing of the competing substantive interests of the debtor (in maximizing the value of its patent portfolio) and US patent licensees (in protecting investments made in reliance on cross-license agreements that would have been protected in a domestic bankruptcy case by section 365(n) of the Bankruptcy Code), the court concluded that the adverse implications for the licensees outweighed the benefit of the requested relief to the debtor.

In Vitro the Fifth Circuit declined to give effect to a Mexican concurso plan in the peculiar circumstances of that case, concluding that section 1507(b)(4) precluded the granting of such relief because the treatment of noteholder claims in the plan was drastically inferior to the treatment they would have received under a comparable chapter 11 plan. Vitro is best regarded as an exceptional case that turns on its own peculiar facts. ${ }^{186}$ The court's statements of general principle do nothing to detract from the view, expressed above, that US courts routinely give US effect to foreign plans even where the relief requested by the foreign representative is not identical to (more generous than) the relief available in a comparable domestic bankruptcy proceeding. ${ }^{187}$ And although the foreign representative lost in both cases, Qimonda and Vitro do not significantly deviate

\footnotetext{
${ }^{186}$ Acceptance of the Mexican plan depended on the votes of Vitro non-debtor subsidiaries that held intercompany debt. As a result of an earlier restructuring, the subsidiaries had been transformed from intercompany debtors into inter-company creditors. The circumstances of the earlier restructuring were opaque to say the least. The plan eliminated guarantees from non-debtor insiders whose votes were critical to plan acceptance. See id., 1038-42, 1052-53.

${ }^{187}$ See id., 1043-45, 1053-54 ("Central to Chapter 15 is comity...Within the context of Chapter $15 . .$. [comity] is raised to a principal objective...In considering whether to grant relief, it is not necessary that the result achieved in the foreign bankruptcy proceeding be identical to that which would be had in the United States. It is sufficient if the result is 'comparable'... Given Chapter 15's heavy emphasis on comity, it is not necessary...that the relief requested...be identical to, or available under, United States law...")
} 
from the prevailing American view that comity is the animating norm of chapter 15 and that limitations on comity must be drawn from within the statute. ${ }^{188}$

As chapter 15 is an addition to the pre-existing Bankruptcy Code instances have arisen where the text of the Code is in tension with the Model Law's stated goals. In these instances involving apparent conflicts of text and purpose, some judges have adopted textualist readings that evidence a more skeptical tendency in US judicial practice as regards reception of the Model Law ${ }^{189}$ - especially among appeals courts that are one or more steps removed from the frontline bankruptcy courts and more generalist than specialist in terms of their expertise.

In In re Barnet, ${ }^{190}$ the Second Circuit ruled that section 109 of the Bankruptcy Code - which determines whether a debtor is eligible to file a case under the various chapters of the Code - also applies to cases filed under chapter 15. Section 109(a) provides that "only a person that resides or has a domicile, a place of business, or property in the United States may be a debtor under this title.” Adopting a plain meaning approach to statutory interpretation, the Second Circuit reasoned that chapter 1 of the Bankruptcy Code, which includes section 109(a), applies to chapter 15 and that "foreign proceedings" involve the "assets and affairs of a debtor." Accordingly, the court concluded that a foreign proceeding can only be recognized under chapter 15 if the debtor in that proceeding is also eligible to be a debtor under the Code as a whole - by meeting

\footnotetext{
${ }^{188}$ See id., 1054 ("Nevertheless, Chapter 15 does impose certain requirements and considerations that act as a brake or limitation on comity, and preclude granting the relief requested..."). The Qimonda decision is less emphatic about comity but acknowledges the statutory reference to it in $\$ 1509$ as well as the tempering mechanisms built into the statutory framework: Jaffé v. Samsung Electronics Company, Limited, 737 F.3d 14, 24 ( $4^{\text {th }}$ Cir. 2013). Of the two decisions, US commentators tend to regard Qimonda as the one that is less easy to justify. See, e.g. Gropper, Curious Disappearance, supra note 74, 172-75; G. Ray Warner, Cross-Border Cooperation in the United States: A Retreat or Merely a Pause?, , 3 NOTT. INSOLV. \& BUS. L. e-J. 393, Dawson, Local Methods, supra note 74, 69-72.

${ }^{189}$ See, generally, Dawson, Local Methods, supra note 74.

190737 F.3d 238 (2d Cir. 2013).
} 
the section 109(a) debtor eligibility requirements. Section 109(a) is a low bar to debtor eligibility for domestic bankruptcy proceedings. ${ }^{191}$ The mere presence of debtor property in the United States will usually suffice. As such, it is straightforward for forum shopping foreign debtors to engineer a full chapter 11 filing. In many chapter 15 cases the additional requirement of debtor eligibility will easily be met because the purpose of the application for recognition will be to deal with the debtor's US assets. But in Barnet, the debtor had no assets in the United States - or none that the Australian foreign representatives knew of. Their purpose in filing the chapter 15 case was to seek discovery against various entities relating to a lawsuit the foreign representatives had commenced in Australia. US courts can grant such relief "upon recognition" in their discretion under section $1521(\mathrm{a})(4) .{ }^{192}$

Critics of Barnet fairly point out that section 109 is concerned with debtor eligibility whereas the sole actor for the purposes of a chapter 15 case is the foreign representative. The Delaware Bankruptcy Court has declined to follow the Second Circuit on precisely this basis setting up a potential circuit split. ${ }^{193}$ However, prudent practitioners in other circuits have to factor the risk that Barnet may be followed in preparing chapter 15 filings. Thus, the resolution of a "text versus purpose" conflict in favor of text in Barnet has added a gloss to the Model Law's recognition framework that

\footnotetext{
${ }^{191}$ See Adrian Walters, “United States' Bankruptcy Jurisdiction Over Foreign Entities: Exorbitant or Congruent", 17 JOURNAL OF CORPORATE LAW STUDIES 367 (2017), http://dx.doi.org/10.1080/14735970.2017.1299841

192 In re Barnet, 737 F.3d 238, 246 (2d Cir. 2013).

${ }^{193}$ In re Bemarmara Consulting A.S., Case No. 13-13037 (KG) (Bankr. D. Del. Dec. 17, 2013). A District Court in the Ninth Circuit sided with the Second Circuit: In re Forge Group Power Pty Ltd., Case No. 172405 (N.D. Cal., Feb. 12, 2018). However, a bankruptcy court in the Eleventh Circuit declined to follow Barnet and its decision survived an appeal to the District Court: Batista v. Mendes, Case No. 17-24308 (S.D. Fla, April 2, 2018).
} 
requires foreign representatives to demonstrate and, if necessary, engineer compliance with domestic rules. ${ }^{194}$

In similar vein, some courts have read the automatic application upon recognition of section 363 to transfers of debtor property within US territorial jurisdiction ${ }^{195}$ as requiring them to conduct a full sales approval process under US law rather than granting comity to a prior approval order of the foreign court. ${ }^{196}$ Commentators have detected in these and other instances a tendency to privilege local interpretive methodologies over more flexible interpretive methodologies that may better reflect the Model Law's international origins and purpose. ${ }^{197}$ Be that as it may, US chapter 15 jurisprudence, as a whole, reveals considerable commitment to a strong version of modified universalism that is presumptively deferential to foreign law.

\footnotetext{
${ }^{194}$ For discussion and criticism see letter dated January 27, 2016 from the National Bankruptcy Conference to Congress available at http://nbconf.org/wp-content/uploads/2015/07/NBC-Ltr-to-Cong-re-Ch-15Amendments2.pdf (asking Congress to disapply $\$ 109$ in chapter 15 cases). See further Daniel Glosband \& Jay L. Westbrook, Chapter 15 Recognition in the United States: Is a Debtor "Presence" Required?, 24 INT. INSOLV. REV. 28 (2015); Dawson, Local Methods, supra note 74, 72-74; Adrian Walters, Recognition of Foreign Insolvency Proceedings in the United States: the Lingering Barnet Problem, 38 COMPANY LAWYER 201 (2017).

19511 U.S.C. $§ 1520(\mathrm{a})(2)$.

${ }^{196}$ In re Elpida Memory, Inc., 2012 WL 6090194 (Bankr. D. Del. Nov. 20, 2012) (“The result here under a plain meaning analysis is straightforward. Section 1520 (a) unequivocally states that 'sections 363,549 , and 552 apply to a transfer of an interest of the debtor in property that is within the territorial jurisdiction of the United States to the same extent that the sections would apply to property of an estate (emphasis added). The emphasized language clearly provides that section 363 and, by implication, its standards are applicable to the transfer of assets located in the United States by a foreign debtor in a foreign main proceeding outside the ordinary course of business."); Krys v. Farnum Place, LLC (In re Fairfield Sentry Ltd.), 768 F.3d 239, 246 (2d Cir. 2014) ("The language of section 1520(a)(2) is plain; the bankruptcy court is required to conduct a section 363 review when the debtor seeks a transfer of an interest in property within the territorial jurisdiction of the United States... The language of the statute makes it plain that the bankruptcy court was required to conduct a section 363 review. Deference to the BVI Court was not required.").

${ }^{197}$ Dawson, Local Methods, supra note 74. Dawson astutely points out (at 79) that courts that defect from the Model Law's language and purpose are not necessarily motivated by territorialist instincts to protect local interests. Sometimes local law (or, for Dawson, local interpretive method) overrides.
} 


\section{2. "Glocal" judging in the UK}

Outward looking judges could conceivably fashion the exercise of discretionary powers under the CBIR along American modified universalist lines, taking cues from experience under the EU Insolvency Regulation, section 426, and the specific adjustments that the CBIR makes to the common law. But that is not what has happened in practice.

It is beyond question that the CBIR explicitly depart from the common law in important ways. They establish rules of recognition based on COMI and establishment that align "third country" cross-border insolvency law with EU law and move away from the common law's insistence that the country of incorporation is the proper venue for winding up proceedings. One consequence is that UK courts will recognize foreign insolvency proceedings relating to UK-incorporated debtors without the necessity for a parallel UK proceeding. ${ }^{198}$ The CBIR also abrogate the rule in Government of India v. Taylor $^{199}$ (which bars recovery of foreign tax claims in UK insolvency proceedings) and trigger automatic consequences in English law that affect procedural rights under English law governed contracts. ${ }^{200}$

But these departures - and proclaimed judicial allegiance to modified universalism - have not led judges to give effect to foreign insolvency law when exercising their discretionary powers. ${ }^{201}$ Instead, judges have used modified universalism

\footnotetext{
${ }^{198}$ In re 19 Entertainment Limited, [2016] EWHC 1545 (Ch).

199 [1955] A.C. 491. See CBIR, art. 13(3).

${ }^{200}$ Samsun Logix Corporation v. DEF, [2009] EWHC 576 (Ch), [2009] B.P.I.R. 1502.

${ }^{201}$ This is illustrated by Pan Ocean discussed in the text infra at III.C.2.c. But Pan Ocean is not an outlier. Consistent with GUIDE TO ENACTMENT, supra note 4, para. 21(b), UK courts craft relief to foreign representatives under discretionary powers in CBIR, art. 21 by reference to the relief available in a comparable UK proceeding. See In re Atlas Bulk Shipping A/S [2011] EWHC 878 (Ch), [2012] Bus. L.R. 1124 (treating the relief available to the foreign representative under art.21 as including that which would be available to a UK office holder in respect of UK insolvency proceedings commenced on the date of
} 
as rhetorical cover to rationalize the grant of judicial assistance to foreign representatives under, and subject to the limits of, UK law. The utility of this approach should not be underestimated. It permits the court to assist foreign representatives to the extent it would ordinarily assist an English liquidator or administrator without the need for a parallel English insolvency proceeding and even in circumstances where the debtor would not strictly be eligible to commence a parallel local proceeding. However, it is a weaker version of modified universalism that does not match the loftier ambitions of universalists because it falls well short of a single, all-encompassing global insolvency proceeding under one law. ${ }^{202}$ Three examples from the case law will suffice to illustrate how the complex, fragmented structure of UK cross-border insolvency law has contributed to a cautious approach to the exercise of judicial discretion under the CBIR reinforcing existing fault lines between UK and US practice.

\section{a. $H I H$}

Re HIH Casualty and General Insurance $L t d^{203}$ was decided before the CBIR came into force. Nevertheless, it is important because it illustrates the prevailing restrictive UK judicial mindset notwithstanding Lord Hoffmann's creative attempt to

commencement of the foreign proceeding); In re 19 Entertainment Limited, [2016] EWHC 1545 (Ch), [11]-[12] ("[T]he effect of the Model Law is to give to the English court the possibility of enabling the position of a company which is in Chapter 11...in the United States, to be put on a similar footing in England...the scheme laid down by [the CBIR] is not to import American law into England, but rather to enable proceedings to be conducted in relation to insolvency matters in England on a footing comparable to the footing under which the matter would be dealt with...in the United States."). Thus, it is standard practice for UK courts to use their powers in CBIR, art.21 to extend the automatic stay provided for in CBIR, art. 20 so as to make the stay in the UK equivalent in scope to the moratorium that takes effect in a UK administration proceeding: id., [20]-[22]. See also In re Peak Hotels and Resorts Limited, [2017] EWHC $1511(\mathrm{Ch})$ (liquidators of BVI debtor entitled in principle to relief under UK statutory lien avoidance powers).

${ }^{202}$ So much so that universalists can justifiably claim that UK judges are mischaracterizing. I concede that "modified territorialism" could well be a more appropriate characterization. But this does not detract from my basic point that what UK judges call "modified universalism" is not understood in quite the same way in the UK as it is understood in much of American legal discourse.

${ }^{203}$ [2008] 1 WLR 852 (UKHL). 
develop an expansive common law principle of modified universalism. $H I H$ concerned an Australian insurance and reinsurance group that was in liquidation in its country of incorporation. HIH group companies were also in parallel provisional liquidation proceedings in England and Wales. At the instigation of the Australian liquidators, the Australian court asked the English court to direct the provisional liquidators to remit assets gathered in the English proceeding for distribution in the Australian liquidation. The issue in $H I H$ arose because of a conflict of priority rules. If reinsurance recoveries in the UK were distributed according to Australian rules, insurance creditors would get a priority they would not enjoy were the English provisional liquidators to distribute the assets in accordance with English law. Creditors who would be better off under English law would be worse off under Australian law and vice versa. The case raised a fundamental question - when acting in ancillary fashion in aid of a foreign main insolvency proceeding does the English court have the power to disapply English statutory distributional rules and, if so, on what basis?

In a speech rightly hailed by universalists as a landmark, Lord Hoffmann opined that the English court had inherent jurisdiction at common law to direct the provisional liquidators to remit assets and, having regard to "the principle of (modified) universalism, which has been the golden thread running through English cross-border insolvency law since the $18^{\text {th }}$ century", that "English courts should, so far as is consistent with justice and UK public policy co-operate with the courts in the country of the principal liquidation to ensure that all the company's assets are distributed to its creditors under a single system of distribution. ${ }^{204}$ But, while the House of Lords as a whole agreed with Lord Hoffmann in the result and directed remittal of the English assets to Australia for distribution under ${ }^{204} I d$., [30]. 
Australian priority rules, only one other judge supported his reasoning. Two judges held that the legal basis for remittal lay in section 426 of the Insolvency Act rather than the common law and a third expressed no view on the common law position. The $H I H$ decision, then, rests ultimately on a statutory not a common law footing: the English court could, in its discretion, safely remit the assets for distribution in a designated country otherwise than in accordance with the English statutory scheme precisely because the statutory scheme (via section 426) so authorized. ${ }^{205}$

$H I H$ illustrates a tendency among UK judges to seek a specific statutory basis in English law for the relief sought by a foreign representative or court and a corresponding unwillingness (contrary to Lord Hoffmann's inclination) to fashion a broad unenumerated discretionary common law power of judicial assistance animated by modified universalism. ${ }^{206}$ Article 21 of the CBIR provides a statutory basis for the English court to

\footnotetext{
${ }^{205}$ Id., [59], [61]-[62] (Lord Scott), [66], [75]-[77], [82] (Lord Neuberger). See also Andrew Godwin et al, The Inherent Power of Common Law Courts to Provide Assistance in Cross-Border Insolvencies: From Comity to Complexity, 26 INT'L. INSOLV. REV. 5, 19-20 (2017).

${ }^{206}$ In the absence of a statutory basis for relief, UK judges have also been loathe to develop the common law of judicial assistance expansively, preferring instead to fashion specific common law powers incrementally by analogy with existing powers. See e.g. Singularis Holdings Limited v. PricewaterhouseCoopers [2014] UKPC 36, [2015] A.C. 1675. This, I believe, is significant. The Judicial Committee of the Privy Council (which decided Singularis) remains the ultimate arbiter of cases from many of the British offshore jurisdictions. Cross-border insolvency law in these jurisdictions is underdeveloped and rests heavily on the common law: see Ian Kawaley, "Relashio": Liberating the Common Law on Judicial Cooperation from its State of Arrested Development - The British Atlantic and Caribbean World, 3 NOTT. INSOLV. \& BUS. L. e-J. 167; Andrew Godwin et al, The Inherent Power of Common Law Courts to Provide Assistance in Cross-Border Insolvencies: From Comity to Complexity, 26 INT'L. INSOLV. REV. 5, 13-14 (2017). My working hypothesis is that UK courts would prefer to see these jurisdictions develop statutory frameworks rather than create an expansive offshore common law that would be at odds with the residual status of the common law in the UK. There is a prevailing unease about the co-existence of an expansive common law that implicates a generous measure of judicial discretion alongside statutory bases of relief even among some creatively inclined offshore judges. See, e.g. In re Saad Investments [2013] SC (Bda) (Bermuda) per Kawaley CJ at [6]: "This is an area of law that in recent times has often been dominated by commercial pragmatism combined with an almost deification of the goal of promoting cross-border co-operation in insolvency cases with an international element, unwittingly no doubt, at the expense of the development of a set of coherent principles."; In re China Agrotech Holdings Limited, FSD 157 of 2017 (NSJ) per Segal J at [26(b)]: "I would, for myself, note that there appears to be an unhelpful tendency in the writings of some commentators to mischaracterise the status and effect of this guiding and flexible principle [of modified universalism] by elevating it into a rigid rule of law that independently generates rights and remedies and is to be treated, and applied, as if it were a
} 
turn over assets to a foreign main or non-main proceeding ${ }^{207}$ and so it is conceivable that English practice in response to requests for remission of assets from foreign representatives in section 426 countries and third countries will become unified. But, Lord Hoffmann's attempt to modernize the common law notwithstanding, the overall message of $H I H$ is that well developed statutory forms of judicial assistance tend to curb the scope for expansive common law development.

\section{b. Rubin}

In Rubin v Eurofinance SA; New Cap Insurance Corpn Ltd v Grant ${ }^{208}$ a 4-1 majority of the UK Supreme Court ${ }^{209}$ declined to recognize and enforce default money judgments entered by a US insolvency court in proceedings brought in a Chapter 11 case under statutory insolvency avoiding powers against defendants who were not present in the United States and had not submitted to the US insolvency court's jurisdiction. Rubin was a turf war about the scope of UK cross-border insolvency law as a whole. The Rubin court's holding stakes out the boundaries of the English law of judicial assistance in international insolvencies (cross-border insolvency law) and resists its encroachment on the common law private international law rules relating to recognition and enforcement of judgments. Rubin's main implication is that, absent specific statutory provision, there is no independent basis in cross-border insolvency law for enforcing judgments entered

doctrine in metaphysics or theology." See also Lord Neuberger, The Supreme Court, the Privy Council and International Insolvency, text of a keynote speech at the International Insolvency Institute Annual Conference, London, June 19, 2017: https://www.supremecourt.uk/docs/speech-170619.pdf (providing insights into the mindset of senior UK judges consistent with my analysis here).

${ }^{207}$ See e.g. In re SwissAir Schweizerische Luftverkehr-Aktiengesellschaft [2009] EWHC 2099 (Ch), [2010] B.C.C. 667 (though in this case a distribution under either Swiss or English law would have produced the same outcome for creditors).

208 [2012] UKSC 46, [2013] 1 A.C. 236.

209 The Supreme Court was established pursuant to the Constitutional Reform Act 2005 (c.4), and replaced the Appellate Committee of the House of Lords as the UK's highest court in 2009. 
during the course of foreign insolvency proceedings. By "judgments entered during the course of foreign insolvency proceedings" I do not mean judgments or orders that commence an insolvency proceeding. The actual insolvency proceeding is squarely the province of cross-border insolvency law. Instead, I mean what international insolvency lawyers now describe as "insolvency-related judgments", i.e. additional judgments and orders made within the insolvency case - proceedings within insolvency proceedings. Two examples of insolvency-related judgments are judgments avoiding antecedent transactions on grounds such as fraudulent transfer (the subject matter of Rubin) and orders confirming a reorganization plan and binding all creditors to the terms of a plan, whether they voted in favor of it or not.

The Rubin court ruled that insolvency-related judgments were no different from other civil judgments and therefore could only be recognized under the ordinary English rules for recognition and enforcement of judgments. ${ }^{210}$ The court rejected the argument that the English court should treat insolvency-related judgments as a special category and give effect to them under Lord Hoffmann's theory of modified universalism. ${ }^{211}$ Writing for the majority, Lord Collins opined that it would be an act of judicial legislation for the courts to create a separate, more liberal regime for recognition and enforcement of insolvency-related judgments within cross-border insolvency law ${ }^{212}$ observing, in passing, that universalism, characterized as the administration of multinational

\footnotetext{
${ }^{210} I d .,[106]-[132]$.

${ }^{211}$ An argument that was open to the foreign representative based on the Privy Council's decision in Cambridge Gas Transport Corp v. The Official Committee of Unsecured Creditors of Navigator Holdings plc, [2006] UKPC 26, [2007] 1 A.C. 508.

212 [2012] UKSC 46, [2013] 1 A.C. 236, [129].
} 
insolvencies by a lead court applying a single insolvency law, was "a trend, but only a trend." $" 13$

Furthermore, the court found no statutory basis in the CBIR or in section 426 for recognition and enforcement of insolvency-related judgments. The court's general discretion to grant relief available to a British insolvency office-holder under UK law and to cooperate with foreign courts and representatives ${ }^{214}$ was not a source of implied authority for the recognition and enforcement of insolvency-related judgments. ${ }^{215}$ Similarly, general powers of assistance in section 426 could not impliedly cover the ground occupied by long-established common law and statutory rules applicable to recognition and enforcement of ordinary civil judgments. ${ }^{216}$

Rubin amplifies the structural differences between US and UK cross-border insolvency law and provides a silent commentary on the lack of any judgments convention between the UK and the US. EU law, for the time being still applicable in the UK, has specific supranational rules on recognition and enforcement of judgments in civil and commercial matters ${ }^{217}$ and makes specific provision in the EU Insolvency Regulation for recognition and enforcement throughout the EU of insolvency-related

\footnotetext{
${ }^{213} I d .,[16]$.

${ }^{214}$ CBIR, arts 21, 25, 27. The British enactment substitutes "may" for "shall" in art.25(1). Cooperation with foreign courts or foreign representatives thereunder is therefore a matter of discretion rather than obligation. Moreover, the British enactment provides that cooperation could be achieved through a British insolvency officeholder and so contemplates the possibility of a complementary parallel proceeding.

${ }^{215}$ [2012] UKSC 46, [2013] 1 A.C. 236, [133]-[144].

${ }^{216} I d$., [145]-[155]. Section 426 did not apply in Rubin because the US is not a designated country. However, its scope was relevant to an appeal by an Australian liquidator in the New Cap Insurance case on an identical question, which was conjoined with the appeal in Rubin.

${ }^{217}$ Regulation (EU) No.1215/2012 of the European Parliament and of the Council of 12 December 2012 on jurisdiction and recognition and enforcement of judgments in civil and commercial matters (recast), 2012 O.J. (L. 351/1). The UK also has reciprocal regimes for the recognition and enforcement of judgments with several jurisdictions with which it has historical or constitutional relationships. These are embodied in the Administration of Justice Act 1920 ( $10 \& 11$ Geo.5 c.81) and the Foreign Judgments (Reciprocal Enforcement) Act 1933 ( 23 \& 24 Geo.5 c.13).
} 
judgments. ${ }^{218}$ The absence of enumerated powers for the recognition of insolvencyrelated judgments in the UK's cross-border insolvency framework for non-EU countries was therefore fatal to the foreign representative's attempt to have the US judgment recognized under cross-border insolvency law. ${ }^{219}$ Rubin consolidates the trend observable in $H I H$ that UK courts are reluctant to grant assistance unless there is a specific UK law basis for the particular relief the foreign representative seeks. It also underscores the UK courts' disinclination to fashion specific relief using broadly couched statutory powers of assistance and cooperation. ${ }^{220}$

One consequence of Rubin is an Anglo-US fault line in the treatment of foreign reorganization plans and foreign discharges of debt. US courts have commonly recognized and given effect in the US to foreign plans and discharges in the form of relief and/or additional assistance under chapter $15 .{ }^{221}$ Under the Rubin holding, UK courts can only give effect to foreign plans and discharges in non-EU insolvency proceedings if they satisfy applicable English private international law rules on the recognition and enforcement of judgments. In a case where UK-based holdout creditors have not

\footnotetext{
${ }^{218}$ EU INSOLVENCY REGULATION, art. 32.

${ }^{219}$ [2012] UKSC 46, [2013] 1 A.C. 236, [24], [142]-[143]. Under the applicable common law rules of personal jurisdiction, the US court lacked jurisdiction to enter judgments against parties who were not present and had not submitted to US jurisdiction at that time: id., [6]-[10]. This has led courts to broaden what qualifies as "submission" to the foreign jurisdiction under these rules. Id., [156]-[167]. See Stichting Shell Pensioenfonds v. Krys, [2014] UKPC 41, [2015] A.C. 2016; Erste Group Bank AG, London Branch v. JSC 'VMZ Red October', [2015] EWCA Civ 379, [2015] 1 C.L.C. 706; Vizcaya Partners Ltd v. Picard, [2016] UKPC 5, [2016] Bus. L.R. 413. For the argument that the UK should simply grant comity to the US's broader rules of personal jurisdiction where due process has been followed in accordance with US constitutional standards see Jodie Kirshner, The (False) Conflict Between Due Process Rights and Universalism in Cross-Border Insolvency, 72 CAMB. L.J. 27, 30-31 (2013).

${ }^{220}$ Other Model Law countries are encountering similar uncertainties on the fault line between cross-border insolvency law and the law relating to the recognition and enforcement of civil and commercial judgments: see e.g. Justice Nye Perram, Issues in Recognition and Enforcement of Foreign Insolvency Judgments - An Australian Perspective, paper for the Judicial Insolvency Network Conference, Singapore, October 10-11, 2016, http://www.fedcourt.gov.au/digital-law-library/judges-speeches/justice-perram/perram-j-20161010

${ }^{221}$ Walters, Giving Effect to Foreign Restructuring Plans, supra note 143. The English rule that contract debts can only be discharged under the governing law of the contract puts a further obstacle in the way of UK judges who might otherwise be minded to give effect to foreign discharges in the UK. See In re OJSC International Bank of Azerbaijan [2018] EWHC 792 (Ch) (appeal pending at the time of writing).
} 
submitted to the foreign jurisdiction, the workaround is a parallel English insolvency proceeding yielding a binding plan and discharge that would be effective in English law ${ }^{222}$ - the kind of duplication that universalists are anxious to avoid. UNICTRAL has proposed a draft Model Law ${ }^{223}$ to deal specifically with insolvency-related judgments that could potentially address the gap in domestic legal provision for judgments not covered by a treaty-based regime such as EU law.

\section{c. Pan Ocean}

In Fibria Celulose S/A v. Pan Ocean Co Ltd, ${ }^{224}$ a Korean-incorporated shipowner in a Korean rehabilitation proceeding had entered a long-term contract expressly governed by English law to charter ships to carry cargo for a Brazilian wood pulp supplier. The shipowner wanted the contract to continue because the freight payable under it was above market rates. The supplier sought to rely on a clause permitting it to terminate the contract in the event of insolvency or the taking of steps in an insolvency proceeding. It was common ground in Pan Ocean that the termination clause was valid as a matter of English law even though other jurisdictions, including the US, outlaw such so-called ipso facto clauses because of concerns that they harm legitimate attempts by debtors to reorganize. ${ }^{225}$ The Korean administrator obtained recognition of the rehabilitation proceeding and asked the English court for relief in the form of an order

\footnotetext{
${ }^{222}$ Walters, Giving Effect to Foreign Restructuring Plans, supra note 143.

${ }^{223}$ U.N. COMM'N ON INT'L TRADE LAW, Working Group V (Insolvency Law), Recognition and enforcement of insolvency-related judgments: draft model law (Note by the Secretariat for the fifty-second session, December 18-22, 2017), U.N. Doc A/AC.9/WG.V/WP.150.

224 [2014] EWHC 2124 (Ch), [2014] Bus LR 1041.

${ }^{225}$ English law tends to be more protective of contractual rights especially in the context of sophisticated commercial transactions. See e.g. Belmont Park Investments Pty Ltd v. BNY Corporate Trustee Services Ltd, [2011] UKSC 38, [2012] 1 A.C. 383.
} 
restraining the supplier from terminating the contract on the ground that the clause was unenforceable under Korean insolvency law.

For universalists the case is a lightning rod. In their estimation, the UK court should have deferred to the law applicable in the Korean proceeding. However, Morgan J. held that the words "any appropriate relief" in the opening language of Article 21(1) of the CBIR, while wide, did not permit the court to grant relief that would not have been available in an English insolvency proceeding. The absence of any express statutory basis for applying foreign law was again fatal as the following passage from the judgment illustrates:

A power for the recognising court to grant relief in that way would be a very significant power. It is odd to think that such a power was intended without there being any specific reference to the recognising court's ability to apply the law of a foreign state, or even to do something which no system anywhere would allow. This is particularly so in view of the terms of sub-paragraph (g) [of Article 21(1)] which deliberately limit relief under that sub-paragraph to relief which would be available to a British insolvency office holder under the law of Great Britain. ${ }^{226}$

\section{d. Summary}

The three cases show powerfully how fidelity to pre-existing local law has shaped the UK's reception of the Model Law. Elsewhere in UK law lines between cross-border insolvency law and judgments recognition and enforcement are clearly drawn. Powers couched in open-ended language supported by enumerated examples (the linguistic structure of Article 21(1)) have not redrawn those lines. The EU Insolvency Regulation and section 426 expressly contemplate the application of the law of the foreign proceeding. This prompts the conclusion that the lack of any express power in the CBIR to apply foreign law is preclusive.

\footnotetext{
${ }^{226}$ [2014] EWHC 2124 (Ch), [2014] Bus LR 1041, [80]. It is true that, by virtue of CBIR, art.2(q), "the law of Great Britain" expressly includes domestic private international law. But the point goes nowhere useful for universalists because the UK's Insolvency Act does not provide a UK officeholder appointed thereunder with a basis for seeking relief under any law other than UK law.
} 
The UK approach to the Model Law is at odds with the US approach in this regard. The Pan Ocean court's reading of Article 21 defaults to the traditional common law approach under the doctrine of ancillary winding up in the absence of any express statutory choice-of-law rule whereas US courts have read the equivalent language in section 1521 of the Bankruptcy Code as permitting them to grant relief under foreign law as well as US law in the absence of a statutory prohibition. ${ }^{227}$

In recent years, much of the jurisprudential debate in the UK has concerned the scope of common law powers and the extent to which UK courts can grant relief by analogy with relief that would be available to an officeholder in a parallel UK proceeding, but without the costs of such a proceeding actually having to be incurred. In its landmark decision in Cambridge Gas Transport Corp v The Official Committee of Unsecured Creditors of Navigator Holdings plc, the Privy Council, speaking through Lord Hoffmann, held that the Manx court could give effect in the Isle of Man to a chapter 11 plan relating to a Manx entity under its common law powers of assistance on the basis that the exact same result could have been achieved under Manx law by means of a winding up and a scheme of arrangement under the Isle of Man Companies Act. ${ }^{228}$ Cambridge Gas proved controversial in the UK because, as well as contemplating an independent basis for recognition of insolvency-related judgments going beyond the common law rules for recognition and enforcement of civil judgments generally (an approach later rejected in Rubin as a judicial overreach), it also implied that courts could

\footnotetext{
${ }^{227}$ See, e.g. In re Condor Ins. Ltd., 601 F.3d 319, 322 (5 $5^{\text {th }}$ Cir. 2010). In similar vein, US courts place far less emphasis on non-bankruptcy choice of law. There is a tradition, already noted, of granting comity to foreign insolvency law even where it overrides contract rights governed by US state law. This is perhaps borne out of the US conception of bankruptcy jurisdiction as all encompassing federal in rem subject matter jurisdiction. For a rare, and probably anomalous, exception see In re SunEdison, Inc. 577 B.R. 120 (Bankr. S.D.N.Y. 2017).

228 [2006] UKPC 26, [2007] 1 A.C. 508, [24].
} 
use common law powers synthetically to procure results that would usually require full compliance with UK statutory procedures. Lord Hoffmann's rationale for broad inherent powers was the "underlying principle of universality" and the desirability of avoiding the costs of additional Manx proceedings. 229 "Why", Lord Hoffmann asked, "should the Manx court not provide assistance by giving effect to the plan without requiring creditors to go to the trouble of parallel proceedings in the Isle of Man?" ${ }^{230}$ A differently constituted Privy Council in Singularis Holdings Limited v. Pricewaterhouse Coopers provided an answer. While endorsing modified universalism as a basis for incremental development of common law powers, the Singularis court rejected as constitutionally improper Lord Hoffmann's conception of a broad judicial power to disapply UK statutory requirements. ${ }^{231}$

Singularis aside, even on Lord Hoffmann's broad view in Cambridge Gas, British modified universalism amounts, at its highest, to a principle for avoiding parallel insolvency proceedings by giving the foreign representative "the remedies to which they would have been entitled if the equivalent proceedings had taken place in the domestic forum." ${ }^{232}$ Indeed, the Cambridge Gas court doubted whether common law assistance "could take the form of applying provisions of the foreign insolvency law which form no part of the domestic system." ${ }^{233}$ And, to date, while the CBIR does authorize UK judges in some respects to apply UK law synthetically without the need for a parallel UK proceeding, British modified universalism, as we have seen, has not embraced the

\footnotetext{
${ }^{229} I d .$, [16], [20].

${ }^{230} I d$., [25].

231 [2014] UKPC 36, [2015] A.C. 1675, [16]-[17], [19], [32], [35]-[36], [38], [64], [82]-[102], [108], [112], [122], [134].

${ }^{232}$ [2006] UKPC 26, [2007] 1 A.C. 508, [22].

${ }^{233} \mathrm{Id}$.
} 
application of foreign insolvency law. It is more restrained than its American cousin: a coordinating rather than a centralizing principle. As Lord Sumption put it in Singularis, “..the principle of modified universalism is part of the common law, but it is necessary to bear in mind, first, that it is subject to local law and local public policy and, secondly, that the court can only ever act within the limits of its own statutory and common law powers." ${ }^{234}$ Current judicial instincts in the UK are therefore cautious and incremental. UK judges look first for a statutory basis for the specific relief sought and, failing that, they are willing to develop the common law only interstitially rather than create expansive, general powers. ${ }^{235}$ Judges, such as the immediate past President of the Supreme Court, have highlighted the difference in view between the US and UK approach $^{236}$ and regard any such inconsistency as a spur to further international legislative action rather than to creative, ends-oriented judicial activism. ${ }^{237}$

D. The limits of modified universalism as an interpretive methodology.

Professor Westbrook argues ${ }^{238}$ that the Model Law is a text that seeks to establish an international system for managing cross-border insolvencies predicated on universalism and that judges should interpret it accordingly. He is right in his assessment

\footnotetext{
234 [2014] UKPC 36, [2015] A.C. 1675, [19].

235 [2006] UKPC 26, [2007] 1 A.C. 508, [25], [38], [65]-[69], [113], [115], [135], [137], [147], [151]-[155], [157]-[161]. See also Ian Kawaley, "Relashio": Liberating the Common Law on Judicial Cooperation from its State of Arrested Development - The British Atlantic and Caribbean World, 3 NOTT. INSOLV. \& BUS. L. e-J. 167, 209 ("Granting common law insolvency assistance by deploying well-defined remedial powers available under the general law is obviously a far more straightforward task than developing or extending an ancient inherent power in aid of a loosely defined principle of 'providing as much assistance as one can."')

${ }^{236}$ Lord Neuberger, The Supreme Court, the Privy Council and International Insolvency, text of a keynote speech at the International Insolvency Institute Annual Conference, London, June 19, 2017: https://www.supremecourt.uk/docs/speech-170619.pdf , [26] ("The extent to which the Model Law promotes substantive universalism (i.e. the application of the law governing the foreign insolvency proceeding) appears to be answered differently in different jurisdictions. Thus, the US courts seem to have adopted a rather more universalist approach than the courts of the UK.").

${ }^{237} I d$.

${ }^{238}$ Westbrook, Interpretation Internationale, supra note 10.
} 
that the structure of the Model Law is such that "one would expect to see considerable success in achieving recognition and a more mixed bag as to relief granted." ${ }^{239}$ This assessment is borne out by the empirical evidence discussed earlier. And while I agree with him that the UK cases discussed above present a contrast with North American experience, I think it is an exaggeration to say that UK judicial attitudes "now hover between hostility and indifference to the Model Law and perhaps to internationalism in general." ${ }^{240}$ My point is not that UK judges are necessarily right in some objective sense. It is entirely defensible to view their current statutory-mindedness as stifling any meaningful development of UK cross-border insolvency law, especially insofar as it relates to third countries. ${ }^{241}$ My point is rather that the decisions in $H I H$, Rubin, and Pan Ocean are perfectly plausible once we pay attention to the Model Law's place in the fragmentary set up of UK cross-border insolvency law in the absence of further local legislative amendment. For this reason, while I dislike the outcome in Rubin, and the tone of the leading opinion, ${ }^{242} \mathrm{I}$ would concede that it is correctly decided (or not clearly erroneous) in a situated sense from a UK lawyer's perspective. Any suggestion that Rubin is an abandonment of modified universalism is overblown. It reflects - as subsequent decisions have borne out - a less potent version of modified universalism encompassing a

${ }^{239} I d ., 743$.

${ }^{240}$ Id., 746. Cf. Lord Neuberger, The Supreme Court, the Privy Council and International Insolvency, text of a keynote speech at the International Insolvency Institute Annual Conference, London, June 19, 2017: https://www.supremecourt.uk/docs/speech-170619.pdf

${ }^{241}$ There are reasonable arguments that statutory innovations like the Model Law should be a spur to creative yet judicious development of the common law and purpose-oriented exercise of statutory discretion. The doctrine of ancillary winding up, for example, is a common law artifact of pre-1986 UK insolvency law developed at a time when the insolvency law of much of the common law world, under the influence of the British Empire, to all intents and purposes was English law. The doctrine is wholly out of step with the late-twentieth century global embrace of rescue and restructuring regimes as a valueenhancing alternative to liquidation. Thus, on one view, the judges could use statutory cues to update ancient common law doctrines of cross-border insolvency but it is not a view that commanded any support from the Privy Council in Singularis. See [2014] UKPC 36, [2015] A.C. 1675, [73]-[75].

${ }^{242}$ See Walters, Giving Effect to Foreign Restructuring Plans, supra note 143 (identifying an unhelpful asymmetry in the UK's approach to foreign discharges compared to that of the US). 
preference for forms of coordination that use the tools of local insolvency law. British modified universalism as currently practiced thus finds expression in Articles 21(g) and 23 of the CBIR. ${ }^{243}$ It grants the foreign representative access to relief that would be available to a British officeholder under local law without the need for a parallel proceeding. Conceivably, relief under Article $21(\mathrm{~g})$ could be wider than relief available under the law of the foreign proceeding - a positive feature. ${ }^{244}$ The post-Rubin debate has focused mainly on the question of the extent to which UK law - especially the common law - permits local law to be used synthetically without following all of the locally applicable statutory formalities ${ }^{245}$ and rather less on the question of the applicability of foreign law.

Westbrook's premise is that the adoption of the Model Law represents the adoption of universalism in insolvency matters. ${ }^{246} \mathrm{He}$ develops his argument in favor of a systemic interpretive rule by reference to Article 8 of the Model Law and comparable interpretive provisions in other international instruments. Article 8 - which is faithfully reproduced in the US and UK enactments - directs courts to have regard to the international origin of the Model Law and the need to promote uniformity in its application. Westbrook argues that uniformity in interpretation is too narrow a goal because pragmatically he doubts "our [i.e. US] courts should follow whatever path has

\footnotetext{
${ }^{243}$ In fairness to Professor Westbrook, I reiterate my concession in note 202 supra. This is not modified universalism as he would understand it. I suspect that he would characterize it as "modified territorialism."

${ }^{244}$ In this respect, the CBIR authorizes relief that is more expansive than that available at common law. It is clear from Singularis that a court cannot exercise its common law powers of assistance to achieve ends that could not be achieved under the law of the foreign proceeding. See [2014] UKPC 36, [2015] A.C. 1675, ${ }^{245}$ One sticking point arises from the UK's private international law rule that contractual obligations are only properly discharged under the law applicable to the contract. Following the rejection of Cambridge Gas in Rubin and Singularis it is not currently possible for a UK court to engineer a synthetic local law discharge as a means of implementing a foreign plan of reorganization. See Walters, Giving Effect to Foreign Restructuring Plans, supra note 143.

${ }^{246}$ Westbrook, Interpretation Internationale, supra note 10, 742. In a footnote he identifies modified universalism as "[t]he most favored doctrine in the current era... which seeks to achieve steady pragmatic progress toward the ideal within the framework of existing political and technological possibilities."
} 
been laid down by courts in other countries, especially where we view that path as wrongheaded in the context of the international system that the instrument seeks to create." ${ }^{247}$ So he would allow judges some leeway to depart from a system-oriented approach. Nevertheless, he proposes a broad "international interpretive rule" under which judges would interpret Model Law enactments in line with the goals of the international system of cross-border insolvency coordination that the Model Law attempts to establish and "consistent with the maximum cooperation and efficiency within an international matrix of courts applying the Model Law". ${ }^{248}$ In pushing back against Rubin and Pan Ocean, Westbrook ushers us towards a modified universalist default principle that courts should presumptively give effect to the lex concursus (at very least - if I read him correctly - as regards the in rem effects of foreign plans of reorganization).

To my mind, the argument overreaches. Westbrook acknowledges that UNCTRAL settled on a Model Law because a widely adopted international insolvency treaty would be difficult to achieve. He also acknowledges that Model Laws are products of compromise. And yet, his argument seems to boil down to the following. By adopting the Model Law, an enacting state is committing to an international system a core principle of which is modified universalism. Judges should behave as system-oriented, purpose governed, modified universalists and interpret Model Law texts accordingly. This way we can achieve what amounts to a back door convention by fashioning a default lex concursus rule out of the Model Law's choice of forum COMI rule. Et voilà! Common unilateralism (countries choosing to enact the Model Law without insisting on

\footnotetext{
${ }^{247} I d ., 751$. The same is true the other way around. It is worth noting that a really powerful role for Article 8 's pursuit of harmonized interpretation would thoroughly Americanize the international insolvency system because the US is by far and away the largest producer of Model Law jurisprudence: see Section I.D., infra. ${ }^{248} I d ., 754$.
} 
formal reciprocity) can be transformed into multilateral universalism sans convention. It is possible that I am over-reading. But even if Westbrook's principle is merely intended to encourage UK judges to apply UK law synthetically across the board, appeals to the Model Law's purpose(s) still meet the roadblock of long-established rules of private international law that have not been expressly displaced.

My account of UK cross-border insolvency law in practice shows why I think Westbrook's argument overreaches. For so long as the Model Law's deliberate indeterminacy on choice-of-law is carried over into local enactments in countries that traditionally provide assistance under local law (as in the UK), it will tend to be selffulfilling - a kind of regression to the mean. Judges from such traditions can perfectly well say that they are doing their best to accomplish the goal of international cooperation by granting relief that would be available under local law. Article 8 directs courts to have regard to the Model Law's international origin and the need to promote uniformity and therefore encourages them to engage with foreign law sources on Model Law enactments. But they are not bound by such sources (which is just as well given the variance in Model Law enactments). ${ }^{249}$ Judges can also legitimately say that general statutory language replete with noble cooperative sentiments ${ }^{250}$ is no substitute for specific legislative commands or hard private international law rules; nor does it override the default structure of local cross-border insolvency law. Hence, modified universalism

\footnotetext{
${ }^{249}$ In Pan Ocean, Morgan J. followed Article 8's direction and took account, inter alia, of the Fifth Circuit's Condor decision but declined to apply it principally because of differences in legislative history and manner in which the UK and US implemented the Model Law. See [2014] EWHC 2124 (Ch), [2014] Bus LR 1041, [93]-[108].

${ }^{250}$ Such as those expressed in the Model Law's preamble and reproduced in 11 U.S.C. § 1501(a)(1). It is also worth noting that CBIR, art. 25(1) departs from the Model Law's mandatory language in providing that "the court may cooperate to the maximum extent possible with foreign courts or foreign representatives..." (emphasis added).
} 
as a principle or methodology gets stuck. It cannot do the work of a convention but apparently asks judges to approximate to a convention where there is none.

Anglo-US experience demonstrates that modified universalism is not a unified phenomenon with a single set of characteristics or predicates. It varies across legal cultures in subtle ways that reproduce the compromise at the heart of the Model Law. ${ }^{251}$ As the Model Law "system" is dominated by the US, the leading producer of Model Law jurisprudence, Westbrook's interpretive principle just seems like an invitation to judges in other Model Law countries to subscribe to a strong, American version of modified universalism. "Glocal" judges are not guaranteed to accept such an exercise of American soft power, ${ }^{252}$ especially those judges who expect to see choice-of-law issues dealt with explicitly by convention or statute rather than by judicial rulemaking. ${ }^{253}$ Thus a harmonizing interpretive principle, freighted with US jurisprudence under chapter 15 ,

\footnotetext{
${ }^{251}$ On the self-reinforcing tendency of legislative compromise in a different context see Graeme Dinwoodie, The Development and Incorporation of International Norms in the Formation of Copyright Law, 62 OHIO ST. L.J. 733, 737 (“As more recent efforts at intellectual property harmonization in the European Union... have demonstrated, achieving comprehensive unification of laws is extremely difficult in areas where divergent national jurisprudence has already taken root. And if unprincipled compromise is forced, either through political log-rolling or language consciously susceptible of all meanings to all parties, national courts steeped in different traditions may re-effect historical divergence.").

${ }^{252}$ On the phenomenon of Americanization of transnational legal process through soft power see Benjamin Brake \& Peter J. Katzenstein, The Transnational Spread of American Law: Legalization as Soft Power, Inst. for Int'l L. and Just. (October 2010), http://www.iilj.org/wp-content/uploads/2016/11/KatzensteinThe-Transnational-Spread-of-American-Law-2010.pdf. I acknowledge, of course, that the assertion of soft power by nations that have the clout and the desire to influence international standard setting will likely have real world effects. But I am skeptical that judges, particularly in the global north, will read the Model Law as a "system" text without further hard law guidance as to what such a system entails.

${ }^{253}$ See Lord Neuberger, The Supreme Court, the Privy Council and International Insolvency, text of a keynote speech at the International Insolvency Institute Annual Conference, London, June 19, 2017: https://www.supremecourt.uk/docs/speech-170619.pdf at [20] (...[I]n highly technical fields, and where cross-border issues are involved, judicial development of the law presents obvious difficulties, when compared with domestic and cross-border law-making by governments and legislators...I did not dissent in Singularis because I am a little Englander. A u contraire: I think that universalism is a noble aim, but I think it is normally better achieved by legislation and treaty-making; and at [26] ("The extent to which the Model Law promotes substantive universalism (i.e. the application of the law governing the foreign insolvency proceeding) appears to be answered differently in different jurisdictions. Thus, the US courts seem to have adopted a rather more universalist approach than the courts of the UK...Hopefully, this is another example of national inconsistencies which will encourage more international legislative action.").
} 
encounters resistance in other countries where local Model Law enactments reinforce local path dependencies.

I should emphasize that my differences with Professor Westbrook are (I think) slight. I share his view that a "plain meaning" approach to statutory interpretation that ignores the purpose and structure of the statute can lead to unintended and unhelpful results. ${ }^{254}$ But in the present context, there is a question of integration and fit, i.e. how is the domestic Model Law enactment to be integrated within the existing corpus juris of the enacting state? Thus, Westbrook prioritizes the Model Law's international origins and goals whereas my focus is on the natural limits of instruments that only acquire legal life through assimilation by domestic legal systems.

\section{THE EVOLUTION OF INTERNATIONAL INSOLVENCY LAW}

Without either a preponderance of highly activist judges or local enactments that go beyond the Model Law's soft "PIL-light" 255 approach, exhortations to courts to behave like American modified universalists and interpret their local Model Law enactments accordingly are not especially useful. This is not to decry the Model Law. On the contrary, I support its "less is more" 256 orientation and believe that the professional international insolvency and restructuring community should continue to promote Model Law enactment and "know how" as one aspect of a multi-dimensional strategy involving international, regional and local lawmaking allied to an increased emphasis on network governance.

${ }^{254}$ See Daniel Glosband \& Jay L. Westbrook, Chapter 15 Recognition in the United States: Is a Debtor "Presence" Required?, 24 INT. INSOLV. REV. 28 (2015) and text to notes 189-194 supra.

255 PIL here is an acronym for private international law. This description of the Model Law was coined in Block-Lieb \& Halliday, Less is More, supra note 9. ${ }^{256} I d$. 
Divergence in transatlantic practice within the common law world reinforces the view that evolution of harmonized cross-border insolvency law frameworks towards greater universalism will depend on legislative incrementalism of the kind engaged in by UNCITRAL, involving recursive cycles of lawmaking and implementation that deepen and broaden the coverage of reform endeavors over time. ${ }^{257}$ Recursivity is already evident in the work of UNCITRAL Working Group V on insolvencies of multinational enterprises and (in response to Rubin) on insolvency-related judgments. ${ }^{258}$ In similar vein, UNCITRAL has already touched on choice-of-law issues ${ }^{259}$ and there is every reason to suppose that the construction of an international choice-of-law rule-andexceptions architecture will feature squarely on UNCITRAL's forward agenda. ${ }^{260}$ The balancing of interests involved in creating such an architecture is such that legislatures are institutionally better placed than courts to define the scope of a lex concursus rule and to consider the principled basis for appropriate exceptions dealing with such matters as security interests, set-off rights, labor contracts, and avoiding powers for which express provision is made in the EU Insolvency Regulation. ${ }^{261} \mathrm{~A}$ strong version of modified

\footnotetext{
${ }^{257}$ See Block-Lieb \& Halliday, Incrementalisms, supra note 9; Terence C. Halliday \& Bruce G. Carruthers, The Recursivity of Law: Global Norm Making and National Lawmaking in the Globalization of Corporate Insolvency Regimes, 112 AM. J. SOC. 1135 (2007).

${ }^{258}$ U.N. COMM'N ON INT'L TRADE LAW, A/CN.9/903, May 26, 2017, Report of Working Group V (Insolvency Law) on the work of its fifty-first session (New York, May 10-19, 2017).

${ }^{259}$ U.N. COMM'N ON INT'L TRADE LAW, UNCITRAL LEGISLATIVE GUIDE ON INSOLVENCY LAW, PARTS $1 \& 2$ (2004), 67-72 recommends that domestic legislatures should consider enacting a lex concursus choice-of-law rule with exceptions for financial markets, payment systems, and labor contracts. See also Gropper, Curious Disappearance, supra note 74, 160-63.

${ }^{260}$ Much current thinking is being directed to that end. See Pottow, Beyond Carve-Outs, supra note 6; Clift, Choice of Law, supra note 26; Edward J. Janger, Silos: Establishing the Distributional Baseline in CrossBorder Bankruptcies, 9 BROOK. J. CORP. FIN. \& COM. L. 180 (2014); Irit Mevorach, Cross-Border Insolvency of Enterprise Groups: The Choice of Law Challenge, 9 BROOK. J. CORP. FIN. \& COM. L. 226 (2014). Choice-of-law harmonization has been a legislative priority at UNCITRAL for a few years. See U.N. COMM'N ON INT'L TRADE LAW, A/CN.9/798, January 8, 2014, Report of Working Group V (Insolvency Law) on the work of its forty-fourth session (Vienna, December 16-20, 2013), para 24.

${ }^{261}$ On the comparative advantage of legislatures in weighing competing (and possibly incommensurable) interests albeit in a different, domestic US context, see Mark D. Rosen, Congress's Primary Role in
} 
universalism may well serve as a useful policy frame for this kind of legislative deliberation. ${ }^{262}$ But there needs to be an open, deliberative debate within international lawmaking fora, rather than buck passing to judges many of whom may (reasonably) be inclined to punt or (as in cases like Qimonda) to use statutory tools such as sufficient protection as a veiled mechanism for applying local law.

Harder and deeper forms of international insolvency law are perhaps most likely to emerge successfully where they are layered onto, and integrated into, existing bilateral and multilateral frameworks for international and regional cooperation. The EU Insolvency Regulation and section 426 of the UK Insolvency Act provide good examples of such an approach. Layering does not treat international insolvency cooperation as discrete but instead involves the construction of unified approaches to private international law on the foundations of pre-existing forms of cooperative ordering. The Insolvency Regulation added a comprehensive scheme of harmonized private international rules to the EU's existing commitments to judicial cooperation in civil matters, powerfully underpinned by norms of mutual recognition and trust. These norms flow from the EU's supranational legal ordering and reflect the breadth and depth of regional economic, legal, and political integration that the EU has accomplished since

\footnotetext{
Determining What Full Faith and Credit Requires: An Additional Argument, 41 CAL. W. INT'L. L.J. 7 (2010).

${ }^{262}$ See Pottow, Beyond Carve-Outs, supra note 6 (proposing modified universalism as a second-order choice of law theory); IRIT MEVORACH, THE FUTURE OF CROSS-BORDER INSOLVENCY: OVERCOMING BIASES AND CLOSING GAPS (2018) (arguing that modified universalism promotes a global approach to cross-border insolvencies that is flexible and capable of adjustment to real world conditions in different transnational settings rather than "one size fits all".). On a separate note, increasing convergence among corporate bankruptcy laws influenced by international and supranational institutions may, over time, reduce the salience of conflict of laws and choice-of-law problems.
} 
1957. ${ }^{263}$ Similar orderings may conceivably arise through bilateral or multilateral trade treaties that could over time (as EU experience has shown) yield mutual recognition frameworks. Section 426 arises from historic family relationships between the UK, its overseas territories and former colonies. It amounts to a lattice of bilateral commitments arrived at by the executive on the basis of a norm of reciprocity and endorsed by the legislature through a system of favored nation accreditation. In similar vein, USCanadian judicial cooperation has gone much deeper than US-UK cooperation. US judges in New York and Delaware and Canadian judges in Toronto are accustomed to coordinating the cross-border insolvency cases that arise from geographical proximity against the background of wider frameworks for regional cooperation (NAFTA). ${ }^{264}$ Of course, this will leave gaps outside of such frameworks, a point underscored by the poor relation status of the UK's "third country" cross-border insolvency regime. But Rome wasn't built in a day.

This is not to say that judges do not have a role to play in creative interpretation and in improving coordination pending further cycles of international and local legislative intervention. They can develop cross-border insolvency law interstitially having regard both to international and domestic law (albeit this will have variable results depending on the manner in which the Model Law is enacted and received into different legal systems and cultures). This may produce some overreaching (cases like Cambridge Gas) and some under-reaching (cases like Rubin) but judicial overreaching and under-

\footnotetext{
${ }^{263}$ The UK's impending departure from the EU does not detract from the basic point that the EU has created strong norms of mutual recognition based on a treaty foundation institutionally reinforced by the Court of Justice.

${ }^{264}$ The depth of US-Canadian cooperation in cross-border insolvencies is such that Canadian and US courts have held joint hearings. See Lauren L. Peacock, A Tale of Two Courts: The Novel Cross-Border

Bankruptcy Trial, 23 AM. BANKR. INST. L.R. 543 (2015). Regional cooperation has a long history. For other examples, see REINHARD BORK, PRINCIPLES OF CROSS-BORDER INSOLVENCY LAW, 8-9 (2017).
} 
reaching can be useful in helping to set forward legislative agendas, UNCITRAL's response to Rubin being a case in point.

Moreover, while the legislative wheels grind slowly forward, judges can establish and develop mechanisms for network governance that will lead to more effective transnational coordination of cases in line with the Model Law's goal of fostering courtto-court communication. ${ }^{265}$ Indeed, meaningful attempts at developing common procedural rules and protocols for case managing complex multinational insolvencies and encouraging communication and cooperation between courts have already been made. ${ }^{266}$

The recently established Judicial Insolvency Network (“JIN"), instigated by the Chief Justice of the Singapore Supreme Court, ${ }^{267}$ represents the latest advance in network governance. Initially comprising judges from Australia, Bermuda, the BVI, Canada, the Cayman Islands, England \& Wales, Singapore, and the US, and with observers participating from other countries, JIN produced guidelines in 2016 that have subsequently been adopted as local rules by courts in Delaware, New York, Florida,

\footnotetext{
${ }^{265}$ On the role of judges and regulators in transgovernmental networks see, e.g. Anne-Marie Slaughter, Judicial Globalization, 40 VA. J. INT'L. L. 1103 (2000) and A Global Community of Courts, 44 HARV. INT'L. L.J. 191 (2003); Kal Raustiala, The Architecture of International Cooperation: Transgovernmental Networks and the Future of International Law, 43 VA. J. INT'L. L. 1 (2002). For discussion of network governance and transnational judicial dialogue in the specific context of international insolvency cooperation see GLOBAL PRINCIPLES, supra note 3, at 38-9.

${ }^{266}$ GLOBAL PRINCIPLES, supra note 3; AMERICAN LAW INSTITUTE, PRINCIPLES OF COOPERATION AMONG THE NAFTA COUNTRIES (2003); EUROPEAN COMMUNICATION AND COOPERATION GUIDELINES FOR CROSS-BORDER INSOLVENCY (2007); JUDICIAL INSOLVENCY NETWORK, GUIDELINES FOR COMMUNICATION AND COOPERATION BETWEEN COURTS IN CROSS-BORDER INSOLVENCY MATTERS (2016).

${ }^{267}$ Singapore is setting out its stall with a view to becoming the leading Asian restructuring hub. As well as the JIN initiative, its courts are showing some willingness to branch out and differentiate Singaporean cross-border insolvency law from its UK counterpart in the context of a spate of legislative reform. See In re Pacific Andes Resources Development Ltd, [2016] SGHC 210, signaling, at [46]-[52], Singapore's willingness to depart from the English rule that debts can only be discharged in accordance with the governing law of the contract. Singapore has also established a specialist international commercial court. See Andrew Godwin et al, International Commercial Courts: The Singapore Experience, 18(2) MELBOURNE J. INT'L L. 1 (2017).
} 
Bermuda, England and Wales, New South Wales and Singapore. ${ }^{268}$ The JIN Guidelines provide for the incorporation of protocols into court orders where there are parallel proceedings affecting a debtor company or group. They draw on existing judicial experience in cases such as Nortel to provide open-ended "soft" case guidelines (including the possibility of innovative practices such as joint hearings). They do not interfere with each court's jurisdiction or affect substantive rights but they do create a methodology for identifying conflicts and determining the sequence in which issues should be resolved with each court being aware of what other courts are doing. The phenomenon of international judicial negotiation ${ }^{269}$ is not new but in the insolvency context it is under-studied. Transnational procedural approaches usefully supplement and flesh out the cooperative mandate of instruments like the Model Law. Moreover, subject to standard caveats about accountability of unelected judicial actors and cross-cultural sensitivities, it makes sense for the frontline actors who have direct experience of cooperation and coordination in practice to lead on developing transnational procedural and case management approaches. ${ }^{270}$ Insofar as transnational case sequencing helps to avoid costly and time consuming jurisdictional conflicts, it serves goals such as judicial economy in which judges are invested. Institutionalized interactions of the sort promoted by JIN and the INSOL Judicial Colloquium will continue to be significant in building trust and in creating the infrastructure of the emerging international forum shopping

\footnotetext{
${ }^{268}$ See http://www.nysb.uscourts.gov/sites/default/files/Chapter15Guidelines.pdf

${ }^{269}$ See Jay L. Westbrook, International Judicial Negotiation, 38 TEX. INT’L L.J. 567 (2003).

${ }^{270}$ See Lord Thomas of Cwmgiedd, Cutting the Cloth to Fit the Dispute: Steps Towards Better Procedures Across Jurisdictions (Singapore Academy of Law Annual Lecture 2016), https://www.judiciary.gov.uk/wpcontent/uploads/2016/10/lcj-speech-singapore-academy-of-law.pdf
} 
system in which cases are allocated primarily according to majority creditor preference. $^{271}$

While I understand American universalist attempts to use the Model Law, and modified universalism, to nudge towards a global lex concursus rule, my article shows that differences in implementation and reception of the Model Law reveal different understandings of modified universalism. These different understandings are not radically divergent. But they do undermine the practical utility of modified universalism as a source of guidance for judges exercising discretionary powers under Model Law enactments. My article serves also (I hope) as a call to international insolvency scholars to shift even more of our collective focus towards the processes and institutions that contribute to the making of international insolvency law.

\footnotetext{
${ }^{271}$ See, e.g. In re Suntech Power Holdings Co., 520 B.R. 399 (Bankr. S.D.N.Y. 2014) (debtor with creditor support choosing to restructure in the Cayman Islands rather than China).
} 